\title{
35. RIDGE FLANK ALTERATION OF UPPER OCEAN CRUST IN THE EASTERN PACIFIC: SYNTHESIS OF RESULTS FOR VOLCANIC ROCKS OF HOLES 504B AND 896A ${ }^{1}$
}

\author{
Jeffrey C. Alt, ${ }^{2}$ Damon A.H. Teagle, ${ }^{2}$ Christine Laverne, ${ }^{3}$ David A. Vanko, ${ }^{4}$ Wolfgang Bach,,${ }^{5}$ Jose Honnorez, ${ }^{6}$ \\ Keir Becker, ${ }^{7}$ Miriem Ayadi, ${ }^{3.8}$ and Philippe A. Pezard ${ }^{3,8}$
}

\begin{abstract}
The lithostratigraphy and alteration of volcanic basement from Holes 504B and 896A, located in different parts of a ridge flank circulation cell, are summarized and compared. The 290-m-thick volcanic section of Hole 896A is located on a basement high that coincides with high heat flow and upwelling fluids. The 571.5 -m-volcanic section of Hole 504B is located $\sim 1 \mathrm{~km}$ away in an area of ambient heat flow. Subtle differences in lithostratigraphy include slightly greater proportions of massive units and fewer pillow basalts in Hole 896A than in Hole 504B. The volcanic sections are geochemically similar, but there is no direct correlation of lithologic or geochemical units between the two sites. Veins are comparable in abundance in the two sections $(~ 30$ veins $/ \mathrm{m}$, mean vein width $<1 \mathrm{~mm})$, but carbonate veins and thick ( $>2 \mathrm{~mm})$ saponite and carbonate veins are more abundant in Hole 896A than in Hole 504B. Permeabilty values of the upper basement sections in Holes 896A and 504B are similar $\left(\sim 10^{-13}\right.$ to $\left.10^{-14} \mathrm{~m}^{2}\right)$, suggesting that the upper $\sim 200 \mathrm{~m}$ of basement is sufficiently permeable on a regional scale to support circulation of seawater through basement.

Alteration effects in basement from Hole 896A are similar to those in the upper $320 \mathrm{~m}$ of volcanic rocks in Hole 504B. These include celadonitic phyllosilicates in fractures and alteration halos and reddish. Fe-oxyhydroxide-rich alteration halos along fractures. Dark gray rocks, characterized by the presence of saponite \pm carbonate \pm pyrite occur throughout Hole $896 \mathrm{~A}$ and the entire Hole 504B volcanic section. Alteration reflects evolution from open circulation of cold, oxidizing seawater, to more restricted circulation of seawater caused by burial of the crust by sediments and sealing of fractures with saponite. Latestage carbonates and minor zeolites formed in veins throughout both holes from reacted seawater fluids (decreased fluid $\mathrm{Mg} /$ Ca). Oxygent and strontium isotopic evidence indicate an early generation of carbonates in both holes that formed at relatively low temperatures $\left(\sim 25^{\circ}-35^{\circ} \mathrm{C}\right)$ during open circulation, whereas later carbonates in Hole 896 A formed at slightly higher temperatures $\left(\sim 50^{\circ}-70^{\circ} \mathrm{C}\right)$ during more restricted circulation, possibly similar to the present ridge flank hydrothermal upflow conditions $\left(\sim 50^{\circ}-80^{\circ} \mathrm{C}\right)$.

Chemical changes in altered upper crust include oxidation, increased alkalis, $\mathrm{Mg}, \mathrm{CO}_{2}$, and $\mathrm{H}_{2} \mathrm{O}$; local uptake of $\mathrm{P}$; elevated $\delta^{18} \mathrm{O}, \delta \mathrm{D}, \delta^{11} \mathrm{~B}$, and ${ }^{87} \mathrm{Sr} /{ }^{86} \mathrm{Sr}$; and lower $\mathrm{S}$ contents and $\delta^{34} \mathrm{~S}$. The greatest chemical changes occur in alteration halos and breccias, and the smallest chemical changes occur in the lower volcanic section of Hole 504B. Secondary minerals filling fractures and cementing breccias are sites of uptake of $\mathrm{Mg}, \mathrm{CO}_{2}$, and $\mathrm{H}_{2} \mathrm{O}$, in addition to changes occurring in altered rocks.
\end{abstract}

\section{INTRODUCTION}

Because of drilling problems in Hole 504B during Ocean Drilling Program (ODP) Leg 148, a second basement hole was drilled on a small bathymetric high about $1 \mathrm{~km}$ southeast of Hole 504B (Figs. 1, 2). Hole $896 \mathrm{~A}$ is situated on a local heat-flow maximum over a basement topographic high, which is the site of upwelling ridge flank hydrothermal fluids. Three main scientific objectives were to be

'Alt, J.C., Kinoshita, H., Stokking, L.B., and Michael, P.J. (Eds.), 1996. Proc. ODP, Sci. Results, 148: College Station, TX (Ocean Drilling Program).

${ }^{2}$ Department of Geological Sciences, 2534 C.C. Little Building, The University of Michigan, Ann Arbor, MI, 48109-1063, U.S.A. Alt: jalt@umich.edu; Teagle: teagle@umich.edu

'Laboratoire de Pétrologie Magmatique, URA CNRS 1277, Faculté des Sciences et Techniques de Saint-Jérôme, Avenue Escadrille Normandie-Niemen, F-13397 Marseille Cedex 20, France. Laverne: lacte@vmesal1.u-3mrs.fr; Pezard: pezard@imtmer1.imtmrs.fr; Ayadi: ayadi@imtmerl.imt-mrs.fr

${ }^{4}$ Department of Geology, Georgia State University, Atlanta, GA 30303-3083, U.S.A. geodav@gsugil.gsu.edu

${ }^{5}$ GeoForschungsZentrum Potsdam, Projektbereich 4.2, Telegrafenberg A50, D14473 Potsdam, Federal Republic of Germany (present address: Universität Potsdam, Institut für Geowissenschaften, Postfach 601553, D-14415 Potsdam. Federal Republic of Germany).wbach@gfz-potsdam.de

Institut de Geologie, Université Louis Pasteur, 1 rue Blessig, F-67084 Strasbourg Cedex, France. honnorez@illite.u-strasbg.fr

'Department of Marine Geology and Geophysics, Rosensteil School of Marine and Atmospheric Science, 4600 Rickenbacker Causeway, University of Miami, Miami, FL 33149,U.S.A. kbecker@rsmas.miami.edu

${ }^{8}$ Laboratoire de Mesures en Forage, Institut Méditerranéen de Technologie, Technopôle de Château-Gombert, F-13451 Marseille Cedex 20, France. addressed by drilling this second hole. The first goal was to examine the heterogeneity of basement alteration in different parts of a ridge flank convection cell; that is, to compare alteration effects in a high heat-flow area where basement fluids are upwelling (Site 896) to alteration in an area where heat flow matches the regional average and fluids are moving horizontally through the uppermost basement (Site 504; Mottl, 1989). The physical properties and hydrogeology of the two sites were also compared to test models for off-axis convection in the crust. The second goal was to examine local variability in volcanic stratigraphy and geochemistry. The third objective was to drill the second of a pair of sites situated across a fault. Hole 504B is located on the inferred hanging wall and penetrates two possible faults (at about $800 \mathrm{mbsf}$ in the lower volcanic section and at $2111 \mathrm{mbsf}$ in the lower dikes), whereas Site 896 is located on the inferred footwall, south of Hole 504B (Fig. 2).

Hole $896 \mathrm{~A}$ penetrates through $179 \mathrm{~m}$ sediment and $290 \mathrm{~m}$ into basement, whereas Hole 504B penetrates through $274.5 \mathrm{~m}$ sediment, a $571.5-\mathrm{m}$ volcanic section, a $209 \mathrm{~m}$ transition zone, and more than 1 $\mathrm{km}$ into the underlying sheeted dike complex (Alt et al., this volume). Although only the upper $\sim 300 \mathrm{~m}$ of the two volcanic sections can be directly compared, these are the intervals having the highest permeabilities and where most of the current ridge flank hydrothermal circulation is thought to occur (Becker et al., this volume; Fisher et al., $1990,1994)$. This paper focuses on a comparison of basement alteration mineralogy and geochemistry, but also presents the basement lithostratigraphy, porosity, and permeability at the two sites. These variations are discussed with respect to location of the sites in a ridge flank convection cell. 


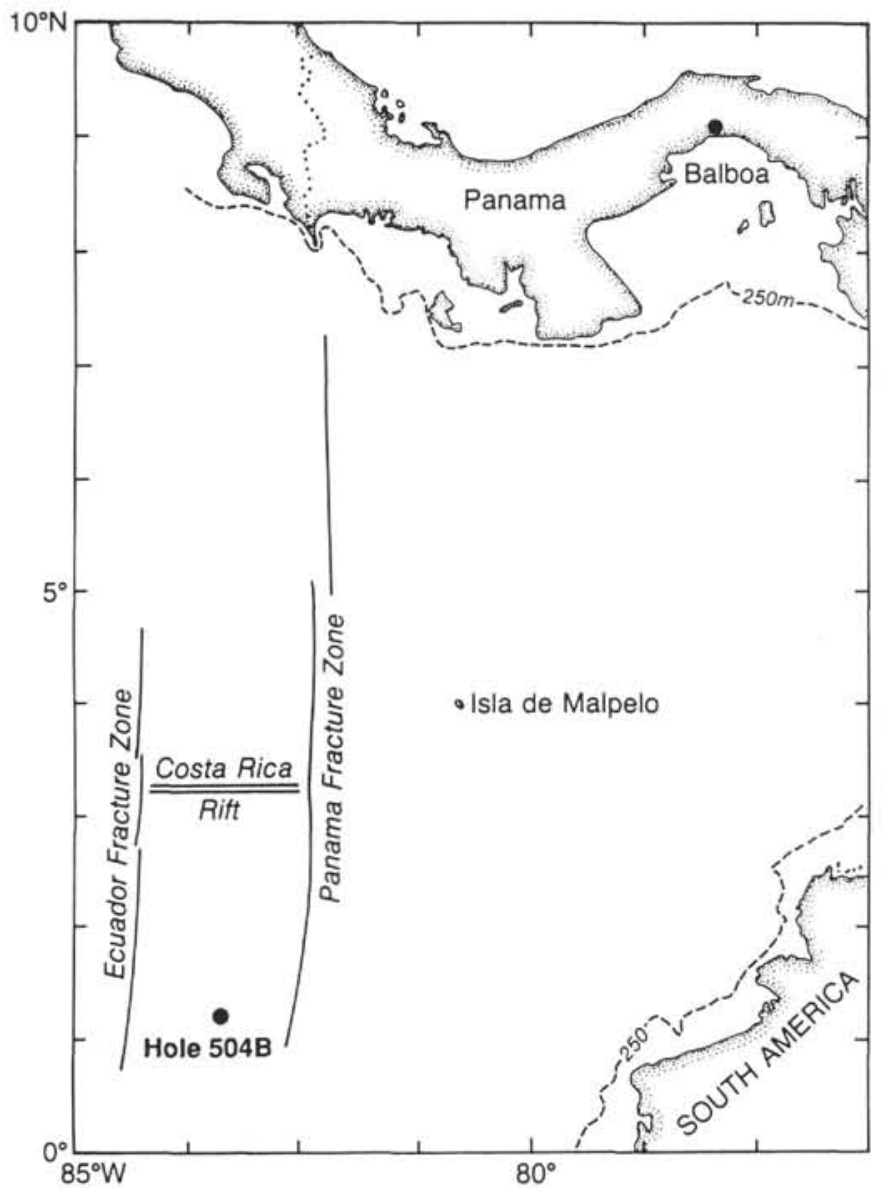

Figure 1. Location of Site 504 in the eastern Pacific.

To quantify alteration effects in the upper ocean crust, the location, width, and mineralogy of veins in recovered cores from Hole $504 \mathrm{~B}$ were measured in the same manner as that utilized for Hole 896A during Leg 148 (J.C. Alt and D.A.H. Teagle, unpubl. data; Alt, Kinoshita, Stokking, et al., 1993). Alteration halos and brecciated intervals were recorded, along with visual estimates of the proportion of breccia matrix and the proportions of different minerals making up the matrix. The entire core from Hole 504B was measured in this manner (J.C. Alt and D.A.H. Teagle, unpubl. data; Alt, Kinoshita, Stokking, et al., 1993; Dick, Erzinger, Stokking, et al., 1992), but only the results for the volcanic section are presented here. Dilek et al. (this volume) present a qualitative comparison of core and log data from Hole $896 \mathrm{~A}$, but detailed comparison of core measurements and geophysical logs has not yet been carried out.

\section{GEOLOGIC SETTING OF SITES 504 AND 896 IN A RIDGE FLANK CONVECTION CELL}

Holes 504B and $896 \mathrm{~A}$ are located $\sim 200 \mathrm{~km}$ south of the Costa Rica Rift in the eastern Pacific (Fig. 1). Age of the crust was originally given as $5.9 \mathrm{Ma}$, but given the location of the holes in Chron $3 \mathrm{Ar}$, the revised geomagnetic polarity time scale places them in 6.6-6.9 Ma crust (Cande and Kent, 1995). Sites 504 and 896 are located in the center of a $171-\mathrm{km}$-long east-west spreading segment, which is bounded by the Panama Fracture Zone on the east and by the Ecuador Fracture Zone to the west. The Costa Rica Rift spreads asymmetrically at an intermediate rate; that is, a half-rate of $3.6 \mathrm{~cm} / \mathrm{yr}$ to the south and $3.0 \mathrm{~cm} / \mathrm{yr}$ to the north (Hey et al., 1977). The high sedimentation

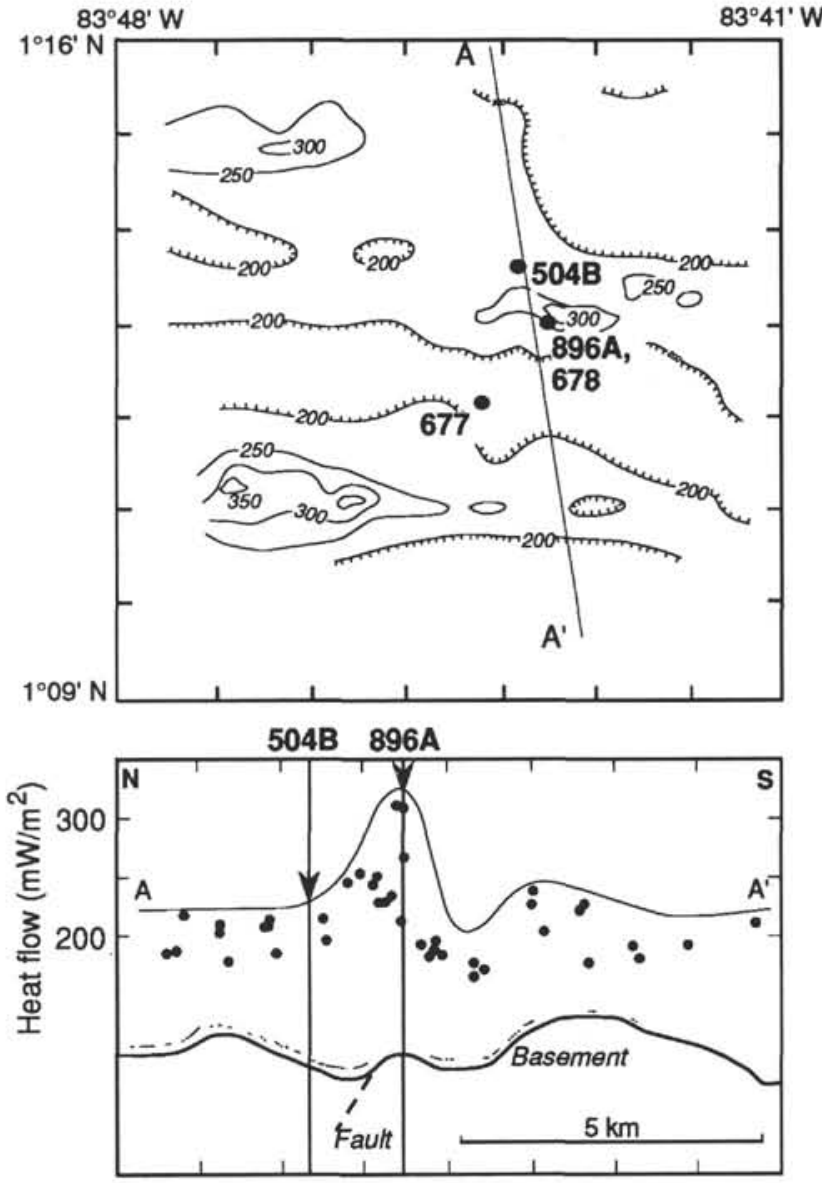

Figure 2. Location of Hole 896A (upper diagram), showing its position relative to Hole $504 \mathrm{~B}$, on a map of heat flow contours $\left(\mathrm{mW} / \mathrm{m}^{2}\right)$. The lower diagram shows cross section $A-A^{\prime}$ of the heat-flow data and the relative basement topography as defined by a single-channel seismic section (adapted from Langseth et al., 1988). The fine line from $A$ to $A^{\prime}$ in the lower diagram outlines the maximum values of heat flow. Predicted conductive heat flow for the area is $194 \mathrm{~mW} / \mathrm{m}^{2}$ (Parsons and Sclater, 1977).

rate $(50 \mathrm{~m} / \mathrm{Ma})$ at Site 504 has resulted in a thick sediment cover over the relatively smooth basement surface (about 100-200 m relief; Cann et al., 1983). The average heat flow around Site 504 falls on the theoretical conductive cooling curve for ocean crust (Langseth et al., 1983), but variations in heat flow and chemical gradients in sediment pore waters reveal continuing convection in basement at Sites 504 and 896 (see below; Langseth et al., 1988; Mottl, 1989).

Site 896 is a reoccupation of Site 678, where the sediment section was cored during ODP Leg 111. Detailed information about the site is given in Becker, Sakai, et al. (1988) and in the Site 678 site survey (Langseth et al., 1988). The basement relief south of the Costa Rica Rift results from the presence of east-west normal faults parallel to the rift axis, which produce south-tilted grabens separated by ridges 1 to $2 \mathrm{~km}$ wide (Langseth et al., 1983; Hobart et al., 1985). The bathymetry of the area around Sites 504 and 896 is characterized by linear east-west ridges and troughs, controlled primarily by the topography of the tilted basement fault blocks. Hole 504B is located on the southern slope of an asymmetric tilted fault block at a water depth of $3460 \mathrm{~m}$. Site 896 is located about $1 \mathrm{~km}$ to the southeast, at a water depth of $3439.8 \mathrm{~m}$, near the crest of a small hill that rises about $30 \mathrm{~m}$ above the surrounding seafloor (Fig. 2). This hill lies near the center of a 4-km-wide trough that runs east-west through the area. Sediments are thinner on the basement highs (171-179 $\mathrm{m}$ at Site 896) than 
in the troughs ( $274.5 \mathrm{~m}$ at Site 504 and $306 \mathrm{~m}$ at Site 677), consistent with seismic refraction results (Langseth et al., 1988; Becker et al., 1988). The ages of basal sediments in troughs and on highs are indistinguishable at the different sites, however (Becker et al., 1988).

Heat flow in the area differs about the conductive value of 194 $\mathrm{mW} / \mathrm{m}^{2}$ predicted for $6 \mathrm{Ma}$ crust (Parsons and Sclater, 1977; Langseth et al., 1983, 1988). General east-west undulations in seafloor heat flow roughly follow the bathymetry, with broad heat flow lows in the sediment troughs and smaller areas with higher than expected heat flow on the ridges (Fig. 2). Measured values of heat flow range from 166 to $395 \mathrm{~mW} / \mathrm{m}^{2}$, with a mean of $218 \pm 36 \mathrm{~mW} / \mathrm{m}^{2}$ (Langseth et al., 1988).

Pronounced vertical and lateral gradients occur in $\mathrm{Ca}, \mathrm{Mg}$, and alkalinity in sediment pore waters from the area (Mottl et al., 1983; Mottl, 1989). Concentrations of Ca increase downward, whereas concentrations of $\mathrm{Mg}$ exhibit a corresponding 1:1 decrease. There is a general positive correlation of chemical and thermal gradients in the area: porewater $\mathrm{Ca}$ and $\mathrm{Mg}$ profiles are convex upward at Site 896 and in other areas of elevated heat flow (Langseth et al., 1988; Mottl, 1989). The porewater concentration profiles change exponentially with depth and asymptotically reach inferred compositions of basement fluids at about $40 \mathrm{~m}$ below seafloor (mbsf). These changes are consistent with the upward flow of basement waters through the sediments at velocities of a few millimeters per year (Mottl, 1989). The compositions of interstitial waters in sediments at the nearby low heat flow Site 677 are nearly constant in the upper $90 \mathrm{~m}$, but approach the inferred basement water composition in the lowermost $40 \mathrm{~m}$, which is consistent with seawater being advected downward through the sediment in the low heat flow areas. The uniformity of inferred basement fluid compositions suggests that fluids move at velocities of several centimeters to several tens of centimeters per year within basement (Langseth et al., 1988; Mottl, 1989).

Measurements of crustal permeability in Hole 504B reveal low permeability values $\left(\sim 10^{-18} \mathrm{~m}^{2}\right)$ in the sheeted dikes, and only the uppermost $200 \mathrm{~m}$ of lavas exhibit significant permeability $\left(10^{-14}\right.$ to $10^{-13} \mathrm{~m}^{2}$; Anderson, Honnorez, Becker, et al., 1985; Becker, 1989). Fisher et al. $(1990,1994)$ demonstrate that convection can occur with large aspect ratio convection cells mainly in the uppermost 200-300 $m$ of the crust.

\section{LITHOSTRATIGRAPHY OF HOLES 504B AND 896A}

The 274.5-m sediment section at Site 504 is divided into three main units (Cann, Langseth, Honnerez, Von Herzen, White, et al., 1983): Unit I (0-143.5 mbsf) consists of siliceous-nannofossil and nannofossil-radiolarian oozes having variable clay contents; Unit II (143.5-227.3 mbsf) is a siliceous nannofossil chalk; and Unit III (227.2-274.5 mbsf) comprises interbedded nannofossil chalk, limestone, and chert. These units are basically diagenetic modifications of the same initial sediment types.

Based on recovered core, the volcanic section (274.5-846 mbsf) is reported to consist mainly of pillow basalts $(47 \%)$, with common massive units $(32 \%)$, thin flows $(17.5 \%)$, and minor dikes $(3 \%$; Adamson, 1985). Recent detailed measurement of drill core, however, reveals the presence of $9.2 \%$ breccia in Hole 504B: $6 \%$ breccia in the upper $320 \mathrm{~m}$ of the volcanic section, and $19 \%$ in the lower volcanic section (Fig. 3) (J.C. Alt and D.A.H. Teagle, unpubl. data). In the Hole 896A lithostratigraphy, thin flows were lumped together with pillows (Alt, Kinoshita, Stokking, et al., 1993), so doing the same for Hole 504B gives $74.4 \%$ pillows (+ thin flows and breccias) in the total volcanic section, consistent with estimates from electrical resistivity logs (Pezard, 1990). For a comparison with the $\sim 300$-m section of Hole 896A, the upper $320 \mathrm{~m}$ of basement of Hole 504B (from shipboard stratigraphy and breccias measured on drill core) comprises $76 \%$ pillows (+ thin flows), $16 \%$ massive units, $6 \%$ breccia, and $2 \%$ dikes.
The sediment section at Site 896 was spot cored to basement at 170.8 mbsf in Hole 678B during ODP Leg 111 (Becker, Sakai, et al., 1988). Four sediment units were recognized: Unit I is radiolarian and diatom ooze (0-27.2 mbsf); Unit II comprises clayey diatom-nannofossil chalk (95.5-111.8 mbsf); Unit III is limestone (111.8-169.8 mbsf); and Unit IV consists of metal-rich muds intercalated with basalt pebbles and conglomerates with white calcitic material (169.8$170.1 \mathrm{mbsf}$ ). Basement was reached at $179 \mathrm{mbsf}$ in Hole $896 \mathrm{~A}$, but coring was not started until $195.1 \mathrm{mbsf}$ because the upper $15 \mathrm{~m}$ was too rubbly and unstable to set casing. The section was cored to 469.0 mbsf, or $289.1 \mathrm{~m}$ into basement. Core recovery was $26.9 \%$, similar to that for the Hole 504B volcanic section (29.8\%) and fairly typical of DSDP-ODP basement holes. The recovered basement core from Hole $896 \mathrm{~A}$ is reported to consist of $57 \%$ pillows, $38 \%$ massive flows, $5 \%$ breccias, and 2 dike margins that comprise $<1 \%$ of total core (Alt, Kinoshita, Stokking, et al., 1993; Fig. 3). Using the same core measuring procedure as for Hole 504B (i.e., the shipboard alteration and vein logs), however, yields $8.6 \%$ breccia, $51.4 \%$ pillows, and $40 \%$ massive units. Thus, Hole $896 \mathrm{~A}$ contains slightly greater amounts of breccia, more massive units, and a smaller proportion of pillows than does the upper volcanic section in Hole 504B. The difference in breccia abundances in these two volcanic sections may not be significant, but assuming that there were no significant differences in processes that affected core recovery in the two holes, the differences in the proportions of massive and pillowed basalts in the two sections is probably real (see below).

On the basis of Formation MicroScanner (FMS) data, Brewer et al. (1995) suggested that Hole 896A actually penetrated a section comprising about $40 \%$ breccia, $30 \%$ pillows, and $30 \%$ massive units. The differences between this stratigraphy and the recovered core could represent biases in recovery (preferential loss of breccias) or difficulties in distinguishing between unconsolidated pillows and breccias in the FMS images (Brewer et al., 1995). To make reasonable and consistent comparisons between Holes 504B and 896A, however, the FMS results are not used in this work.

It is possible that core recovery is related to the presence or absence of veins and fractures along which the core breaks into small pieces and is ground up during drilling. At 305 mbsf in Hole 896A the minimum in vein abundance corresponds to very low core recovery $(1.3 \%$ for the $9.5-\mathrm{m}$ interval; Fig. 3$)$, but otherwise there is no good correlation between core recovery and the frequency of veins for either hole (Fig. 4). Although there is significant scatter, there is a tendency for cores with higher recovery to contain lower amounts of breccia than cores having low recovery (Fig. 4). Aboard JOIDES Resolution during Leg 148, the general impression was that massive units had better recovery than pillow units (Alt, Kinoshita, Stokking, et al., 1993), but there is no good correlation between the proportion of massive basalt material in a given core and the core recovery (Fig. 4). These data indicate that there is no simple relationship between core recovery and the abundance of veins, breccias, and massive units in cores from Holes 504B and 896A.

Other volcanic sections with much higher percent recovery have no consistent relationships between recovery and the proportions of pillows, massive units, and breccias. Overall core recoveries in DSDP Holes 417A, 417D, and 418A (62\%, 72\%, and 72\%, respectively) are much greater than in Holes 504B and 896A (27\%-30\%), presumably because the former holes are located in much older crust (110 Ma in the Atlantic) and are more tightly cemented by secondary minerals (Donnelly, Francheteau, Bryan, Robinson, Flower, Salisbury, et al., 1979). Core recovery in Hole 417A is similar in both pillows and breccias (both $\sim 66 \%$ ), but lower in massive units (45\%). In contrast, recovery in Hole $418 \mathrm{~A}$ is greater in massive units $(81 \%)$ than in pillows or breccias $(64 \%-68 \%)$, and in Hole $417 \mathrm{D}$, breccias had better recovery than pillows or massive units $(92 \%$ vs. $72 \%$, respectively; Donnelly, Francheteau, Bryan, Robinson, Flower, Salisbury, et al., 1979). The data for these holes support the conclusion from Holes 504B and 896A, that is, that there is no simple relation- 


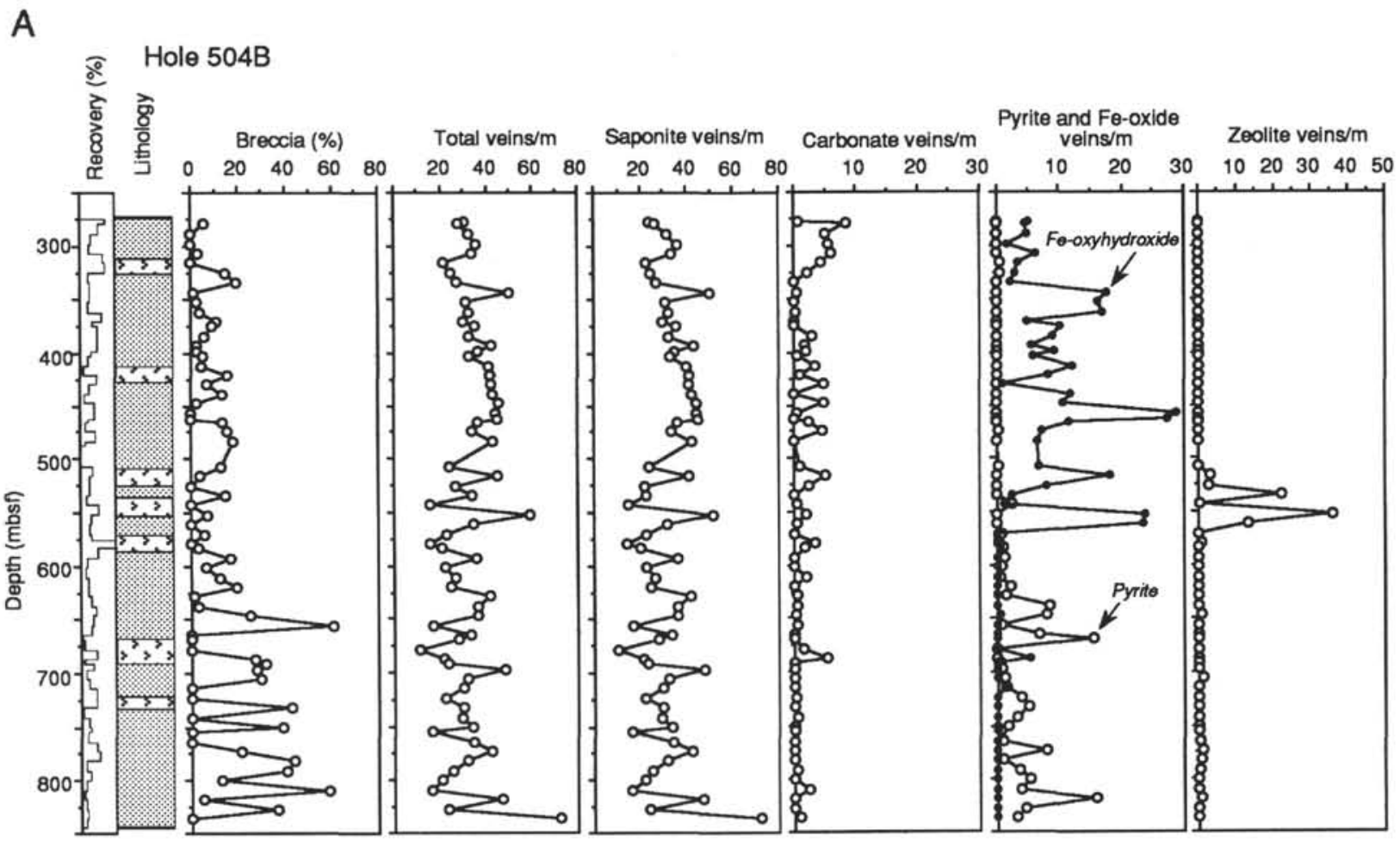

B

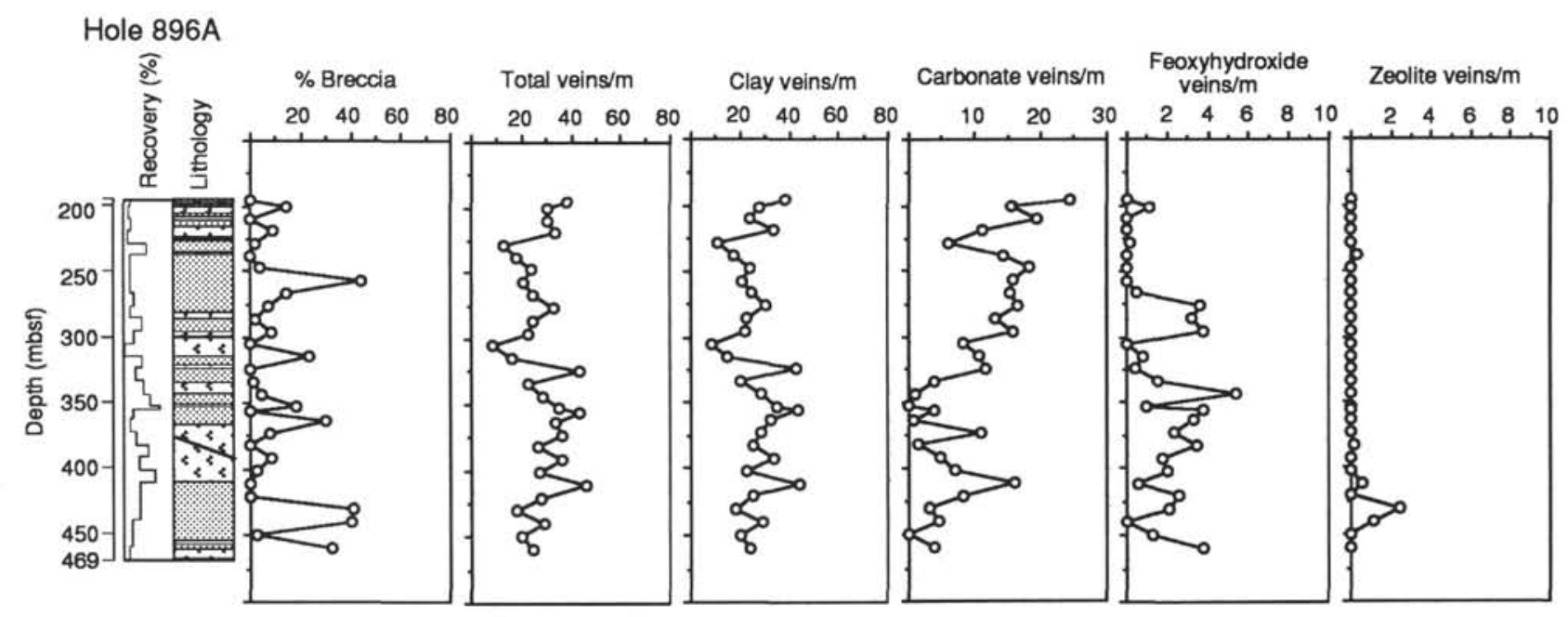

Figure 3. Lithostratigraphy and breccia and vein abundances for Hole 896A (A) and the volcanic section of Hole 504B (B). Breccias are plotted as percentage of recovered core for each cored interval, and veins are plotted as average number of veins per meter for each cored interval. Recovery is shown on scale from $0.6 \%$ to $100 \%$. Zero recovery at about $500 \mathrm{mbsf}$ in Hole 504B corresponds to end of drilling on DSDP Leg 69 and beginning of drilling on Leg 70. For the lithology, pillows and thin flows are shown by shaded zones, and massive units are shown by "v's." Veins are plotted as "mineral-bearing" veins and thus may be plotted more than once: that is, a saponite + Fe-oxyhydroxide + carbonate vein is plotted as a saponite-bearing vein, a carbonate-bearing vein, and a Fe-oxyhydroxide-bearing vein.

ship between recovery and the abundance of veins, breccias, and massive units.

Variable magnetic inclinations of rocks below $350 \mathrm{mbsf}$ in Hole $896 \mathrm{~A}$ reflect tilting of this portion of the crust before extrusion of the 145-m-thick Unit A (Allerton et al., this volume; Stokking et al., this volume). In nearby Hole 504B, a similar variation in magnetic inclination occurs beneath the 56-m-thick Unit 1 , where inclinations fit those predicted for the site, and this likewise may reflect tilting of the deeper section before extrusion of the uppermost units (Furuta and
Levi, 1983; Allerton et al., this volume). This record of tilting of the uppermost crust during accretion at the axis is commonly observed in other DSDP drill cores (e.g., Dmitriev, Heirtzler, et al., 1978; Melson et al., 1978; Natland, 1979; Donnelly, Francheteau, Bryan, Robinson, Flower, Salisbury, et al., 1979). General decreases of natural remanent magnetization intensity and magnetic susceptibility below $\sim 350$ mbsf in Hole 896A are similar to trends observed in the volcanic section of Hole 504B, and reflect a general increase in the abundance of massive units having larger grain sizes downward in both holes (Al- 

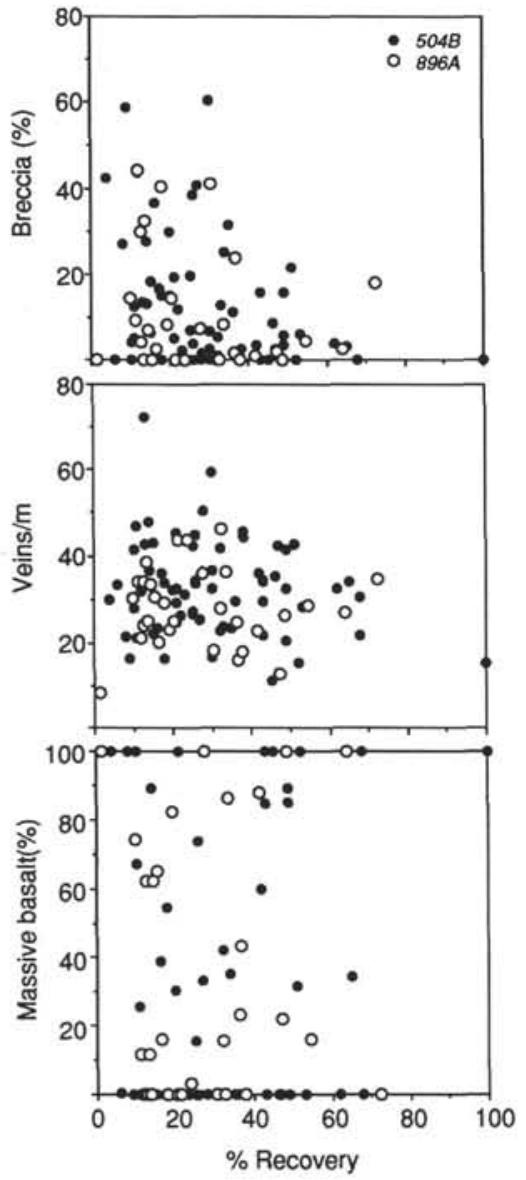

Figure 4. Percent breccia, average number of veins per meter, and percent massive basalt vs. percent recovery for each cored interval in Holes 504B and $896 \mathrm{~A}$. There is no correlation of veins $/ \mathrm{m}$ with recovery, but cores with the highest recovery have the lowest proportion of breccias. Similarly, cores with the lowest recovery range to the highest percentage of breccia. There is no clear relationship between the proportion of massive units and core recovery. The proportions of massive units per core were calculated based on the lithostratigraphy given by Adamson (1985) and Alt, Kinoshita, Stokking, et al. (1993).

lerton et al., this volume; Stokking et al., this volume; Furuta and Levi, 1983).

\section{IGNEOUS PETROLOGY AND GEOCHEMISTRY OF VOLCANIC ROCKS FROM HOLES 504B AND 896A}

Rocks recovered from the volcanic section of Hole 504B are aphyric to highly phyric tholeiitic basalts, which are divided into five major types: plagioclase-olivine-spinel phyric basalts; aphyric to sparsely phyric basalts (variable phenocrysts); plagioclase-olivineclinopyroxene phyric basalts; highly plagioclase-olivine-clinopyroxene phyric rocks; and moderately plagioclase-olivine phyric basalts (Cann, Langseth, Honnerez, Von Herzen, White, et al., 1983). On the basis of phenocryst assemblages and textures, 71 lithologic volcanic units were defined (Cann, Langseth, Honnerez, Von Herzen, White, et al., 1983; Anderson, Honnorez, Becker, et al., 1985).

The basalts from Hole 896A are sparsely to highly phyric tholeiites (Alt, Kinoshita, Stokking, et al., 1993). Fifty lithologic units were recognized on the basis of phenocryst assemblages and textural differences. All but two of these units are sparsely to highly phyric pla- gioclase-olivine ( \pm spinel) basalts or olivine-plagioclase ( \pm spinel) basalts. The two exceptions are moderately olivine-phyric basalts. Plagioclase-olivine phyric basalts make up $90 \%$ of the units in the upper basement (195.1-390.1 mbsf), whereas olivine-plagioclase phyric lavas make up $72 \%$ of the lower section (390.1-469 mbsf). Clinopyroxene is present as an additional phenocryst phase from 353.1 to 392.1 mbsf. Basalts throughout the core contain a variety of megacrysts and glomerocrysts, including plagioclase, plagioclaseolivine, plagioclase-clinopyroxene, and plagioclase-olivine-clinopyroxene.

Nearly all volcanic rocks from Hole 504B are primitive to moderately evolved mid-ocean ridge basalt (MORB), with $\mathrm{Mg}$ numbers in the range $0.60-0.70$ (Autio and Rhodes, 1983). These rocks are unusually depleted in incompatible elements (Fig. 5; Group D, $\mathrm{TiO}_{2}=$ $0.7 \%-1.2 \%, \mathrm{Nb}<0.5-1.2 \mathrm{ppm}$, and $\mathrm{Zr}=34-60 \mathrm{ppm}$ ), but have incompatible element ratios similar to normal I-type MORB as defined by Bryan et al. (1976). The refractory nature of these basalts is also illustrated by their high $\mathrm{CaO} / \mathrm{Na}_{2} \mathrm{O}$ ratios (5-8), which are in equilibrium with exceptionally calcic plagioclase at liquidus temperatures. The basalts have been interpreted as being very primitive (Emmermann, 1985; Natland et al., 1983), or the result of multistage melting of a normal MORB mantle source followed by moderate extents of crystal fractionation (Autio and Rhodes, 1983; Kempton et al., 1985). Two volcanic units (one in the upper $300 \mathrm{~m}$ ) are enriched- or transitional-type MORB (Fig. 5; Group M; Autio and Rhodes, 1983; Etoubleau et al., 1983). Variations in trace element ratios between Group $M$ and Group D rocks suggest possible variations in their mantle source compositions (Etoubleau et al., 1983; Emmermann, 1985).

Fifty chemical units, comprising eight chemical types, occur in the Hole 504B volcanic section (Autio and Rhodes, 1983; Emmermann, 1985). All of the lithologic and chemical units are less than 60 $\mathrm{m}$ thick. Despite subtle variations in chemistry, the overall uniformity in composition of the basalts has been interpreted to indicate the presence of a steady-state magma chamber beneath the rift axis (Natland et al., 1983). Cyclical variations in the chemical stratigraphy suggest influxes of new magma into a differentiating magma chamber (Autio and Rhodes, 1983; Natland et al., 1983). Different phenocryst assemblages and phenocryst zonations suggest periodic mixing of magmas from two different depths in the crust (Natland et al., 1983).

Basalts from Hole $896 \mathrm{~A}$ are strongly depleted, moderately evolved MORB, and all are similar to the Group D basalts from Hole 504B (Fig. 5; Brewer et al., this volume). In contrast to Hole 504B, however, no enriched or transitional-type MORB (Group M) have been found in Hole $896 \mathrm{~A}$, and only 5 chemical units are recognized in the core on the basis of major and trace element variations (Fig. 5; Brewer et al., this volume). Incompatible trace element patterns indicate a single mantle source for all the lavas (Brewer et al., this volume). The sawtooth pattern in various elements with depth (e.g., $\mathrm{TiO}_{2}, \mathrm{~V}, \mathrm{Cr}, \mathrm{Ni}$ ) below 340 mbsf results from differentiation and magma mixing, whereas the gradual trend in the 145-m-thick Unit A reflects progressive mixing with more primitive melts toward the top (Brewer et al., this volume).

Although the rocks recovered from both holes are similar geochemically, there is no direct correlation of lithologic or geochemical units between the two holes (Alt, Kinoshita, Stokking, et al., 1993). This general lack of correlation between closely spaced drillholes in upper oceanic crust is typical, even for holes as close as $100 \mathrm{~m}$, and must reflect the geometry and size of lava flows (Melson et al., 1978; Aumento, Melson, et al., 1977; Natland, 1978; Donnelly, Francheteau, Bryan, Robinson, Flower, Salisbury, et al., 1979).

\section{ALTERATION OF VOLCANIC ROCKS}

\section{Hole 504B}

Alteration of basalts from Hole 504B is described in detail elsewhere (Noack et al., 1983; Honnorez et al., 1983; Alt, 1984; Alt et al., 
Figure 5. Some whole-rock chemical data for Holes 504B and $896 \mathrm{~A}$. The $\mathrm{TiO}_{2}$ and $\mathrm{P}_{2} \mathrm{O}_{5}$ contents illustrate igneous variations: the depleted nature of rocks from both holes (Group D rocks); the presence of high-Ti, high-P rocks (Group M) at $\sim 400$ and 700 mbsf in Hole 504B; and the fine vertical scale $(<60 \mathrm{~m})$ of igneous variations in both holes, with the exception of the much thicker (145 m) Unit $\mathrm{A}$ at the top of Hole 896A (195-340 mbsf). $\mathrm{K}_{2} \mathrm{O}$ contents and $\mathrm{Fe}^{3+} / \mathrm{Fe}^{T}$ ratios illustrate the similarity of alteration effects in Hole 896A to the upper portion of the Hole 504B volcanic section. The $\mathrm{Fe}^{3+} / \mathrm{Fe}^{\mathrm{T}}$ ratios decrease downward in both holes. Locally high $\mathrm{P}_{2} \mathrm{O}_{5}$ contents in Hole $896 \mathrm{~A}$ are alteration effects.
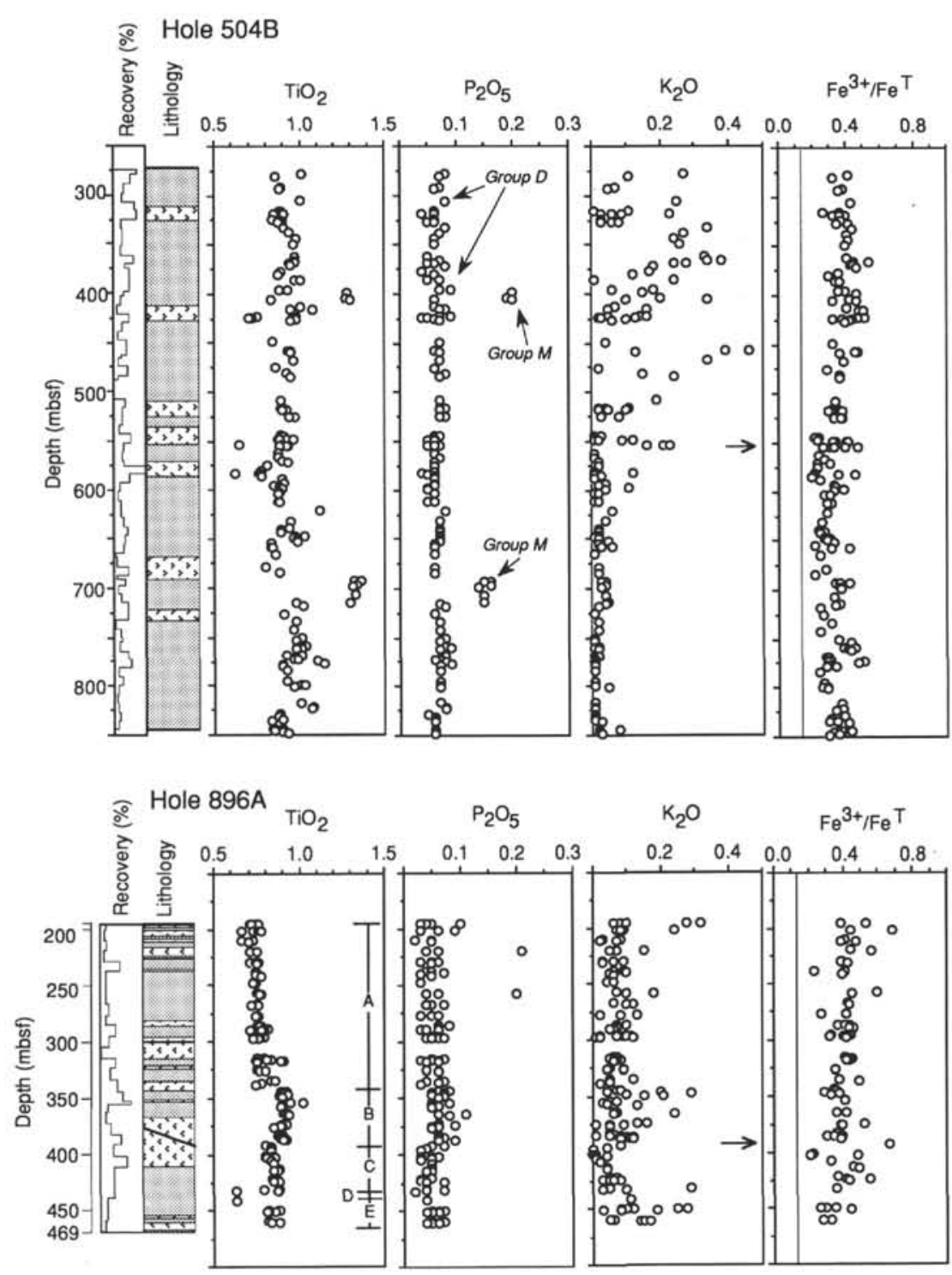

1986a, 1986b; Laverne, 1987) and is summarized here. The volcanic section is divided into upper and lower alteration zones (274.5-594 and 594-846 mbsf; Fig. 6; Honnorez et al., 1983; Alt et al., 1986a). All of the basalts from throughout the volcanic section are slightly altered, containing $5 \%-15 \%$ secondary minerals (not including veins and breccia cements). Three basic alteration types are distinguished: (1) dark gray rocks occur throughout the volcanic section; (2) reddish and (3) black alteration halos occur along fractures and veins in the upper alteration zone. The dark gray rocks are characterized by the presence of saponite, which partly to totally replaces olivine, fills pores and fractures, cements breccias, and partly replaces plagioclase and glassy pillow rims. Small amounts of talc are also present. Carbonates and minor pyrite are typical accessory minerals, and rare $\mathrm{K}$ feldspar and albite occur in a few samples.

Reddish alteration halos, $0.5-2 \mathrm{~cm}$ wide, occur along fractures in the upper alteration zone (Fig. 7). Alteration of these zones is similar to those of the dark gray rocks, but the red color is caused by the presence of abundant $\mathrm{Fe}$-oxyhydroxides replacing olivine, disseminated in the groundmass, and staining saponite. Celadonitic phyllosilicates are also locally abundant replacing olivine and filling pores within red halos (Fig. 8). These phyllosilicates range from nearly pure celadonite to mixtures of celadonite with saponite, nontronite, and Fe-oxyhydroxides (Honnorez et al., 1983; Alt et al., 1986a). Recent detailed measurements of the Hole 504B drill core reveal that red halos comprise $22 \%$ of the upper volcanic section at Site 504 (Fig. 9; Alt, 1995b). The abundance of red halos reaches maxima in many massive units (up to $50 \%-70 \%$ at $\sim 320,420$, and 520 mbsf), but not in the massive unit at $550 \mathrm{mbsf}$ (Fig. 9).

Narrow black alteration halos, up to $0.5 \mathrm{~cm}$ wide, occur along fractures and on one side of many red halos (Figs. 7,8). The black halos are characterized by abundant celadonite replacing olivine and filling pores, with only minor amounts of saponite and Fe-oxyhydroxides present. Black halos make up $2.3 \%$ of the upper volcanic section in Hole 504B, and appear to be more abundant in the core where red halos are less abundant (Fig. 9). This relationship is most likely the result of overprinting of early black halos by later red oxidation effects, that is, that black halos can no longer be identified in hand specimen because of the abundant Fe-oxyhydroxides in the rocks (see Discussion section).

\section{Hole 896A}

Some differences between alteration effects in Holes 896A and 504B were emphasized in preliminary results (Alt, Kinoshita, Stokking, et al., 1993): for example, greater abundance and thicknesses of veins in Hole 896A; much greater abundance of breccias in Hole $896 \mathrm{~A}$; a lack of celadonite-bearing black alteration halos in Hole 


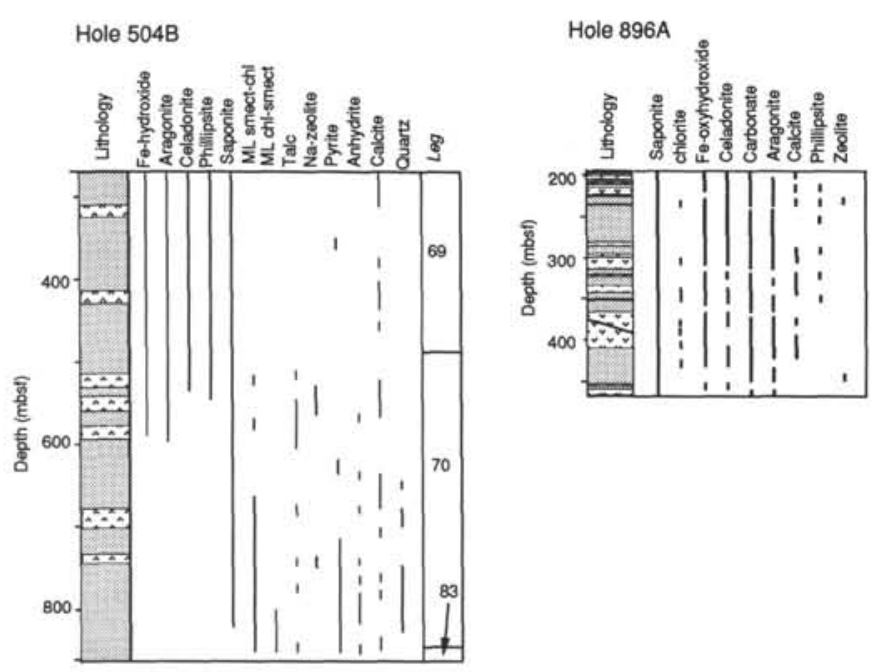

Figure 6. Distribution of secondary minerals with depth in Hole 896A and in the volcanic section of Hole 504B (after Alt et al., 1986a: Alt, Kinoshita, Stokking, et al., 1993; Laverne et al., this volume; Teagle et al., this volume). Alteration in Hole $896 \mathrm{~A}$ is essentially identical to that in the upper volcanic section of Hole 504B.

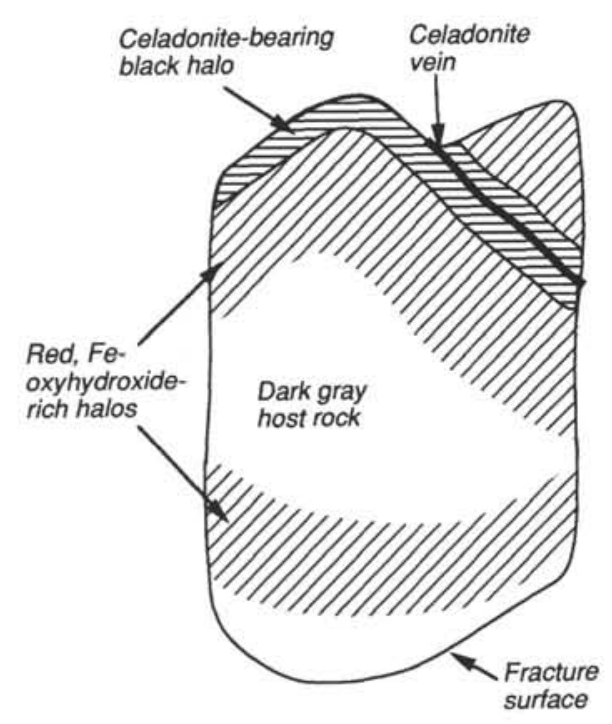

Figure 7. Sketch of a hand specimen from the upper volcanic section of Hole $504 \mathrm{~B}$ illustrating a typical occurrence of red and black alteration halos in dark gray host rock. This is but one of numerous geometries of alteration halos in the two holes. See text and Figure 8 for further description and discussion.

$896 \mathrm{~A}$; and greater sealing of basement by secondary minerals in Hole $896 \mathrm{~A}$. However, upon reexamination of the data it is clear that alteration in both holes is similar and that differences exist only in a few significant details (e.g., the greater abundance of thick smectite and carbonate veins in the upper half of Hole 896A than in the lower part of the core or in Hole 504B, and perhaps differences in the $\mathrm{Sr}$ and $\mathrm{O}$ isotopic compositions of smectite and carbonate veins from the two holes; see following sections).

Alteration effects in rocks from Hole 896A are summarized here from detailed descriptions given elsewhere (Alt, Kinoshita, Stokking, et al., 1993; Teagle et al., this volume; Laverne et al., this volume; Honnorez et al., this volume). Alteration of the $290-\mathrm{m}$ section of Hole $896 \mathrm{~A}$ is comparable to that of the upper volcanic section of Hole
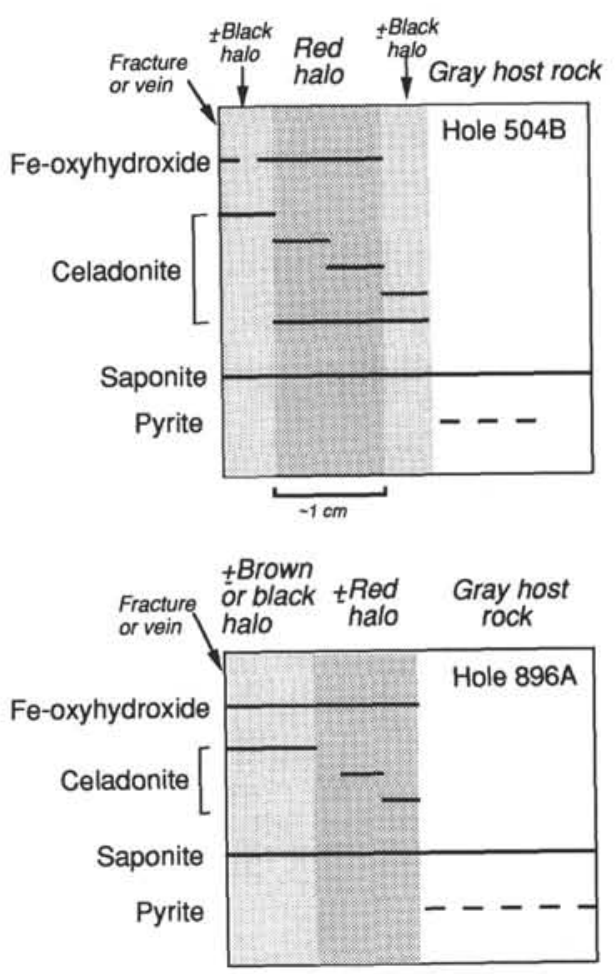

Figure 8. Distribution of secondary minerals in alteration halos around veins and fractures in Hole 896A and the upper volcanic section of Hole 504B (after Alt, 1984; Laverne et al., this volume; Teagle et al., this volume). The mineralogy and distribution of secondary minerals in altered rocks from the two holes are essentially identical. See text for further description and discussion.

504B, and includes the same three alteration types: (1) dark gray basalts and (2) reddish and (3) black alteration halos around veins.

The dark gray basalts are essentially identical to those from Hole $504 \mathrm{~B}$. Although the more detailed descriptions of reddish alteration halos in Hole 896A reveal greater variations in their morphology and occurrence, the mineralogy and distribution of secondary phases in these alteration halos are similar to that in Hole 504B (Fig. 8). The centimeter-sized, reddish alteration halos are best developed in coarser grained massive units of Hole 896A, whereas basalt pillows do not generally display distinct centimeter-scale zonations. This can be seen in Figure 9, where the proportion of red halos reaches maxima associated with massive units at $\sim 300-310,330$, and 370-410 mbsf, similar to the relationship in Hole 504B. Red halos comprise $31 \%$ of the core from Hole $896 \mathrm{~A}$, similar to but slightly greater than the proportion in Hole 504B $(22 \%)$. Variations in reddish alteration halos in Hole $896 \mathrm{~A}$ include compound, or zoned halos in massive basalts, millimeter-wide brown halos in pillow basalts, and uniform brownish coloration of fine grained portions of basalt pillows (Alt, Kinoshita, Stokking, et al., 1993; Laverne et al., this volume). Although the proportions vary, the secondary mineralogy of all these variations of reddish halos is similar. Besides the typical saponite, celadonite, and Feoxyhydroxides in these rocks, two brownish breccias in Hole 896A contain small amounts of $\mathrm{K}$-feldspar replacing plagioclase (Teagle et al., this volume). The celadonites in Hole 896 A exhibit the same mineralogical and chemical variations as those from Hole 504B (Laverne et al., this volume; Teagle et al., this volume).

Dark gray or "black" alteration halos were observed in hand specimens of only two pillow basalts from Hole 896A (Alt, Kinoshita, Stokking, et al., 1993), although thin section examination reveals that three other samples also contain the characteristic celadonite-rich, 
Figure 9. Distribution of red and black alteration halos in Holes 504B and 896A. Data plotted as percentage of alteration halo for each cored interval. Maxima in abundance of red halos tend to coincide with the occurrence of massive units in both holes.
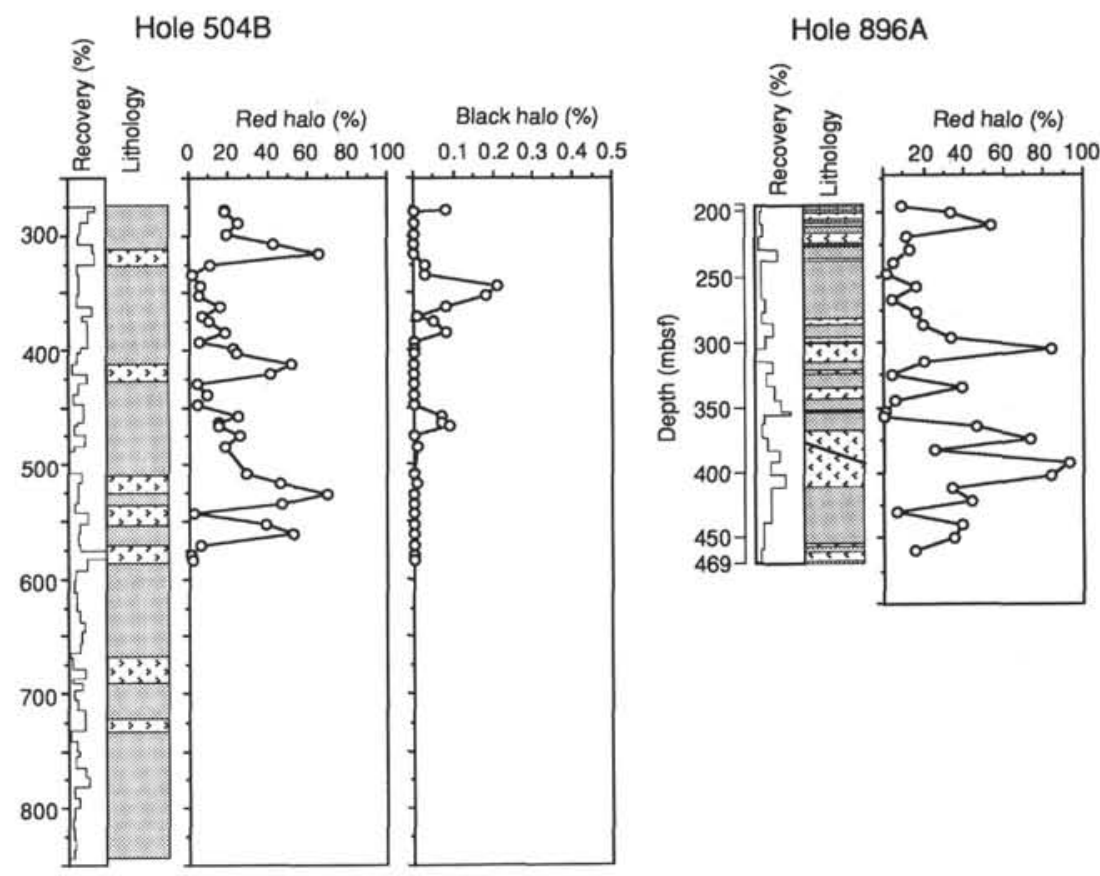

Fe-oxyhydroxide-poor secondary mineral assemblage (Teagle et al., this volume). As in Hole 504B, the black bands in Hole 896A have been overprinted by alteration that produced the reddish $\mathrm{Fe}$-oxyhydroxide-rich bands (Teagle et al., this volume; Laverne et al., this volume; see "Discussion" section below).

Trace amounts of chlorite in interstices of the coarse-grained portions of massive units and in two samples of pillows or thin flows from Hole 896A formed early during initial cooling of the lavas (Teagle et al., this volume; Laverne et al., this volume). Similar occurrences of chlorite have been observed in other massive flows and pillows from the seafloor, including those from Hole 504B (Böhlke et al., 1980; Alt and Honnorez, 1984; Alt et al., 1986a).

\section{Veins and Breccias}

The mineralogy of veins in the two cores is essentially identical, although minor variations occur: the mineralogy of zeolites varies locally in Hole 504B and thick (>2 mm) smectite and carbonate veins are more common in Hole 896A than in Hole 504B. Small amounts of quartz and anhydrite also occur in veins and breccias of the lower volcanic section from Hole 504B but were not observed in Hole 896 A (Fig. 6). The sequence of secondary mineral formation in veins, vugs, and breccia cements is also the same in both holes. This sequence can be summarized as follows: (1) early celadonite $\pm \mathrm{Fe}$-oxyhydroxides; (2) Fe-oxyhydroxdes \pm saponite; (3) saponite \pm pyrite \pm carbonate; and finally, and (4) late carbonate \pm zeolites.

The location and thickness of secondary mineral veins were measured in core from both holes (Alt, Kinoshita, Stokking, et al., 1993; J.C. Alt and D.A.H. Teagle, unpubl. data). A total of 2018 veins was measured in Hole 896A for an average of 27.4 veins $/ \mathrm{m}$ (Fig. 3). The minimum in vein abundance at 305 mbsf in Hole $896 \mathrm{~A}$ corresponds to only $1.3 \%$ recovery ( $12 \mathrm{~cm}$ of core) and is probably not representative. In the volcanic section of Hole 504B, 5280 veins were measured (3424 in the upper volcanic section) for an average of 31.6 veins/m (34.3 in the upper volcanic section). Veins in both holes range up to $11 \mathrm{~mm}$ wide, but most of the veins are less than $1 \mathrm{~mm}$ wide: $98 \%$ of veins in Hole 504B and $90 \%$ in Hole $896 \mathrm{~A}$ are $\leq 1 \mathrm{~mm}$ wide. A significant difference between the two holes is the abundance of thicker veins: 54 saponite \pm carbonate veins are $>2 \mathrm{~mm}$ wide

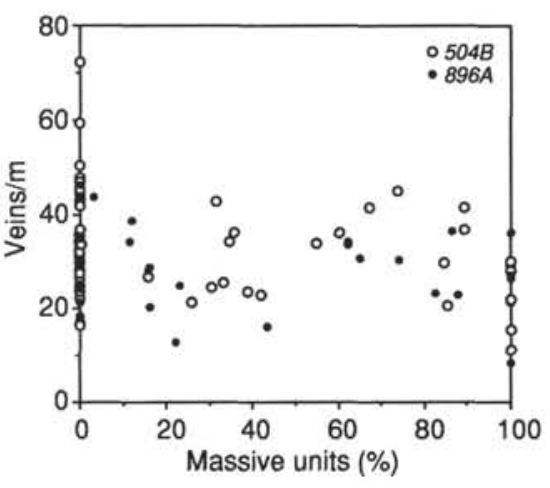

Figure 10. Abundance of veins vs. proportion of massive units for each core from Hole $896 \mathrm{~A}$ and the volcanic section of Hole 504B.

in Hole 896A, whereas only 17 are $>2 \mathrm{~mm}$ wide in Hole 504B. Given that the core recoveries from the two holes are nearly identical and the crust is essentially the same age at the two sites, it seems unlikely that the variation in abundance of thick veins is related to coring and recovery processes. There is no good correlation of the abundance of veins with the proportion of massive basalt for each core (Fig. 10), but cores consisting completely of massive basalt have generally lower vein abundances than those comprising $100 \%$ pillows.

Saponite is by far the most abundant vein mineral (Figs. 3, 11). Saponite occurs in $97 \%$ of all veins in Hole 504B, and saponite in veins comprises $0.8 \%$ by volume of all volcanic material recovered from the hole. In Hole 896A, 93\% of the veins contain saponite, and saponite in veins makes up $1.7 \%$ of the recovered core. Carbonate is more common in veins of Hole $896 \mathrm{~A}$, occurring in $30 \%$ of all veins ( $0.4 \mathrm{vol} \%$ of core) compared with only in $6 \%$ of all veins in Hole 504B (or $0.04 \mathrm{vol} \%$ of core) (Figs. 3, 11). Both cores exhibit general downward decreases in the abundance of carbonate veins. Blocky and fibrous carbonate veins as well as calcite and aragonite are present in veins of both holes. Evidence for replacement of fibrous aragonite by blocky calcite also exists in both holes (Alt et al., 1986a; Tartarotti et al., this volume). 
Hole 504B

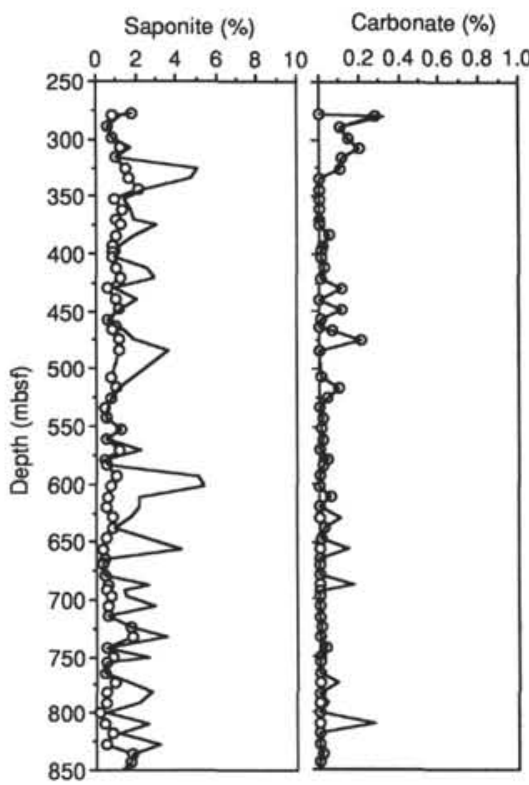

Hole 896A
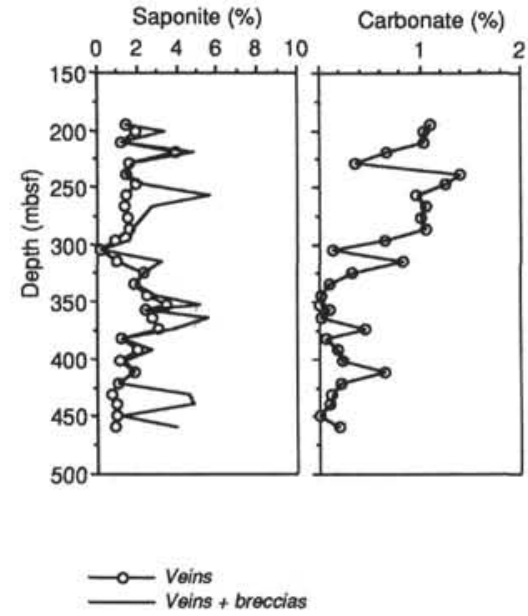

Figure 11. Abundance of saponite and carbonate in veins and breccias of Holes 504B and 896A. Percentages are calculated from abundance, thickness, and mineralogy of veins measured in recovered core relative to amount of recovered core for each cored interval. Breccias are calculated on the basis of measured percentage of breccia recovered for each cored interval, assuming all breccias have the average breccia composition for Hole 504B ( $10 \%$ breccia matrix, comprising $94.5 \%$ saponite, $5.2 \%$ zeolite, and $0.3 \%$ carbonate).
Saponite veins in Hole 896A are massive, vermicular, or fibrous, and all textures commonly occur intergrown with carbonate minerals. Carbonate tends to be late in veins, however, and fibrous saponite and carbonate veins tend to cut earlier saponite veins (Alt, Kinoshita, Stokking et al., 1993; Harper and Tartarotti, this volume; Tartarotti et al., this volume). Similar fibrous saponite, carbonate, and saponite + carbonate veins are common in Hole 504B and other DSDP/ODP drill cores (e.g., J.C. Alt and D.A.H. Teagle, unpubl. data; Alt and Honnorez, 1984; Alt et al., 1992; Alt, 1993).

Zeolite veins are uncommon and narrow $(<1 \mathrm{~mm})$ for the most part in both holes, consisting mainly of phillipsite and rare analcite and natrolite. One large (5 mm thick) analcite + natrolite vein (or elongate vug?) was recovered from Hole 896A, however, and a zone of abundant zeolite veins occurs at 525-575 mbsf in Hole 504B (Fig. 3 ). The latter veins range up to $1 \mathrm{~cm}$ wide and include natrolite, mesolite, thompsonite, analcite, gyrolite, apophyllite, calcite, and aragonite, as well as saponite, celadonite, and Fe-oxyhydroxide (Honnorez et al., 1983; Alt et al., 1986a). The occurrence of Fe-oxyhydroxide bearing and pyrite bearing veins in Hole 504B are mutually exclusive (Fig. 3), and their distribution correlates with other alteration effects (oxides and sulfides) that define the upper and lower volcanic sections (Fig. 6).

A preliminary comparison between the total number of veins per meter measured in recovered core and events per meter as determined from the FMS log (averaged over $10 \mathrm{~m}$ intervals) is shown in Figure 12. The events detected in FMS images are interpreted as veins and open fractures (see de Larouzière et al., this volume, and Alt, Kinoshita, Stokking, et al., 1993, for details of FMS logging). The average number of events picked from the FMS images is somewhat less than the number of veins measured in core from Hole 504B, whereas the opposite is true for Hole 896A. The core measurement data are also more noisy than the FMS data. These differences may be in part because of differences in the scale of resolution of the FMS compared to the human eye, but core recovery may also be important. Where recovery is very low (e.g., at $305 \mathrm{mbsf}$ in Hole 896A and at 420, 500, 670, and 730 mbsf in Hole 504B; Fig. 12), measurement of vein abundances in the core may not be representative. Despite average core recovery of $26 \%-29 \%$ vs. essentially $100 \%$ FMS vertical coverage, the FMS and core measurements track each other over several intervals in Hole 504B: at 325, 400-475, 575, and $675 \mathrm{mbsf}$ to the base of the volcanic section (Fig. 12). Discrepancies between the FMS and core measurements are greater in Hole 896A, however (Fig. 12).

Breccias in Hole 896A were divided into three types (Alt, Kinoshita, Stokking, et al., 1993): (1) pillow rim or hyaloclastite breccias, containing glass shards and pillow fragments cemented by saponite, carbonate, and minor zeolites; (2) jigsaw-puzzle breccias, where angular clasts cemented by saponite and minor carbonate can be fit back together; and (3) "other" breccias, which commonly are matrix supported, contain heterogeneous clast lithologies and alteration, and have clasts cemented by saponite and minor carbonate. Identical breccias occur in the volcanic section from Hole 504B (J.C. Alt and D.A.H. Teagle, unpubl. data), and have been observed in other DSDP/ODP volcanic sections (e.g., Alt, 1993). Minima in breccia abundance and in the proportion of veins in the cores tend to coincide with massive units in both holes (Figs. 3, 10), but correlations are poor.

The proportion of matrix in breccias was not measured in cores from Hole 896A, but in Hole 504B the matrix comprises an average of $10 \%$ of recovered breccia material (range $=2 \%-100 \%$; J.C. Alt and D.A.H. Teagle, unpubl. data). The breccia matrix in Hole 504B is dominantly saponite (averaging $94.5 \%$ ) with lesser zeolite $(5.2 \%)$ and minor carbonate $(0.3 \%)$. Although most breccias in Hole $896 \mathrm{~A}$ are similar to those from Hole 504B, some of the pillow rim/hyaloclastite breccias from Hole 896A have carbonate-rich matrices (e.g., see Alt, Kinoshita, Stokking, et al., 1993, pp. 148-149, figs. 41, 42).

\section{Whole-Rock Chemistry}

Bulk rocks from the upper volcanic section of Hole 504B exhibit increased $\mathrm{K}, \mathrm{Rb}, \mathrm{B}, \mathrm{CO}_{2}$, and $\mathrm{H}_{2} \mathrm{O}$ contents; elevated $\delta^{18} \mathrm{O}, \delta \mathrm{D}, \delta^{11} \mathrm{~B}$, ${ }^{87} \mathrm{Sr} /{ }^{86} \mathrm{Sr}$, and $\mathrm{Fe}^{3+} / \mathrm{Fe}^{\mathrm{T}}$; and lower $\mathrm{S}$ contents and $\delta^{34} \mathrm{~S}$ relative to the compositions of least altered rocks and fresh glass (e.g., Fig. 5; see Alt et al., this volume, figs. 5, 6; Honnorez et al., 1983; Hubberten et al., 1983; Noack et al., 1983; Barrett, 1983; Barrett and Friedrichsen, 1982; Alt et al., 1986a, 1986b; Ishikawa and Nakamura, 1992). Red and black halos generally exhibit the greatest chemical and isotopic changes. The lower volcanic section has undergone chemical changes similar in direction to those of the upper volcanic section, but generally of smaller magnitude. 


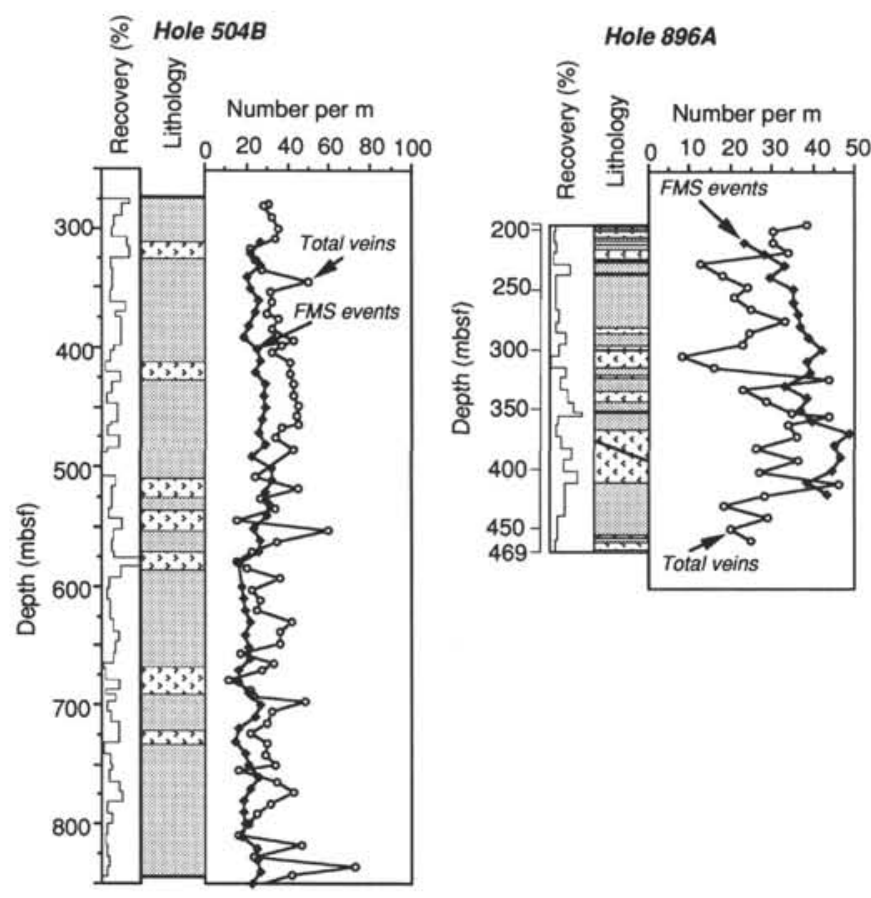

Figure 12. Comparison of total veins per meter measured in recovered core (from Fig. 3) and events per meter, averaged over 10-m intervals, as identified on FMS images (de Larouzière et al., this volume; M. Ayadi and P.A. Pezard, unpubl. data). FMS events are interpreted as veins and open fractures. Lithology and recovery as in Figure 3.

Altered rocks from Hole $896 \mathrm{~A}$ exhibit chemical changes generally similar to those from Hole 504B (Fig. 5; Teagle et al., this volume; Laverne et al., this volume; Honnorez et al., this volume). Enrichments of $\mathrm{K}_{2} \mathrm{O}, \mathrm{CO}_{2}, \mathrm{H}_{2} \mathrm{O}, \mathrm{Fe}^{3+} / \mathrm{Fe}^{\mathrm{T}}, \delta^{18} \mathrm{O}$, and bulk ${ }^{87} \mathrm{Sr} /{ }^{87} \mathrm{Sr}$, and losses of $\mathrm{S}$ in the basement section of Hole $896 \mathrm{~A}$ are generally similar to enrichments in the upper volcanic section of Hole 504B (cf. figs. 5 and 6 of Alt et al. [this volume] and fig. 5 of Teagle et al. [this volume]). Chemical data for bulk rocks from Hole $896 \mathrm{~A}$ also indicate increases in concentrations of $\mathrm{Cs}, \mathrm{Li}$, and $\mathrm{U}$, locally elevated $\mathrm{P}_{2} \mathrm{O}_{5}$, increased $\mathrm{Tl}$ concentrations in sulfide-rich rocks, and little or no change in rare earth elements (Teagle et al., this volume). The greatest chemical changes occur in the reddish halos and in breccias. Based on the extreme chemical changes that occur in breccias, Teagle et al. (this volume) pointed out the importance of breccias as sites of mass and isotopic exchange between seawater and the crust. The single breccia analyzed from Hole 896A contains K-feldspar and celadonite, both of which contribute to the extreme alkali-enrichment of this sample. In general, however, $\mathrm{K}$-feldspar is rare in these two holes. Several breccias from Hole 504B exhibit chemical changes that are among the greatest in rocks from that hole, but the changes are not as extreme as for the breccia from Hole 896A.

\section{DISCUSSION}

\section{Evolution of Thermal and Chemical Conditions}

Petrographic observations indicate that the earliest alteration processes resulted in the formation of celadonite in fractures and in black alteration halos along fractures in both holes (see Fig. 13). Temperatures of formation for celadonite in other seafloor rocks range up to about $40^{\circ} \mathrm{C}$ (see references in Alt, 1995a). Chemical analyses of black halos from Holes 896A and 504B, as well as from other seafloor rocks, indicate that $\mathrm{Fe}$ (as well as $\mathrm{K}$ and $\mathrm{Rb}$ ) has been added to

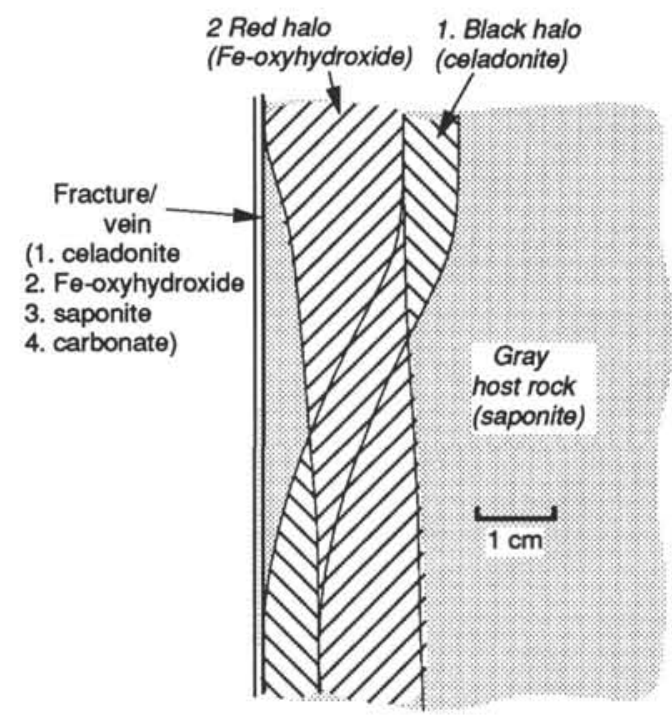

Figure 13. Sketch illustrating the formation of red and black alteration halos around veins and fractures and the origin of mineralogical zonations shown in Figure 8. First, black halos form along veins or as bands within the rock, up to $1-2 \mathrm{~cm}$ away from the fracture. Next, red halos may form in the rock, either along the fracture or within the rock slightly away from the fracture, and either superimposed upon or adjacent to the black halo. The different geometries of these superimposed alteration halos, resulting from different alteration processes and stages, can account for the observed variations in secondary mineralogy and distribution of alteration halos in cores from Holes 504B and 896A. Black or red halos also occur alone in gray rocks of both cores.

the rocks, which in turn suggests the presence of Fe-bearing, lowtemperature hydrothermal fluids (Laverne et al., this volume; Teagle et al., this volume; Laverne and Vivier, 1983; Alt and Honnorez, 1984; Böhlke et al., 1984; Alt, 1993). These fluids could be derived from local reactions (breakdown of glass and titanomagnetite), but could also be derived from deeper in the volcanic pile, or could even be distal, low-temperature hydrothermal fluids mixed with seawater. Given the early appearance of such black halos $(<10,000 \mathrm{yr}$; Adamson and Richards, 1990), it is also possible that the Fe-enriched solutions may result from reactions during initial cooling of hot lavas, or from water-rock interactions during diking events. Whatever the process, such alteration features form in the uppermost volcanic section in young crust, and are typical of DSDP/ODP drilled volcanic sections in MORB crust (e.g., Alt, 1995a).

Following the local formation of black halos, reddish Fe-oxyhydroxide-rich alteration halos formed along fractures in both Holes 504B and 896A (Fig. 13). These red halos are the result of reaction of the rocks along fractures or open spaces with large amounts of cold, oxidizing seawater flowing along the fractures. Subtle downward decreases in $\mathrm{Fe}^{3+} / \mathrm{Fe}^{\mathrm{T}}$ and ${ }^{87} \mathrm{Sr} /{ }^{86} \mathrm{Sr}$ in both holes and a stepwise downward decrease in $\mathrm{K}_{2} \mathrm{O}$ contents in Hole 504B suggest a decreasing influence of seawater. Compared to the lower volcanic section of Hole 504B, Hole 896A and the upper section of Hole 504B were altered by larger volumes of seawater, freely circulating through the uppermost volcanic pile. This circulation caused the greater oxidation and alkali enrichment of the upper rocks, particularly in alteration halos around fractures (Fig. 5). Estimates of integrated seawater/rock mass ratios required to produce the oxidation and $\mathrm{K}$ enrichment observed in the volcanic section of Hole 504B range from 2 to 900 , but the most reasonable values are probably about 10-100, with the higher ratios in the upper volcanic section (Alt et al., 1986a, 1986b). 
Open circulation of seawater through the upper crust occurs in ridge flank circulation systems relatively near spreading axes, where there is little sediment cover and circulation of large volumes of seawater through the crust maintain low temperatures $\left(<25^{\circ} \mathrm{C}\right)$ in the volcanic section (Mottl and Wheat, 1994; Wheat and Mottl, 1994; Alt, 1995a). The compositions of fluids circulating through basement are little changed from normal seawater, and oxidizing conditions prevail in the basement. Similar conditions have been inferred on the basis of whole rock chemical changes in basement rocks (e.g., Alt and Honnorez, 1984; Alt et al., 1986a; Alt, 1993). The formation of $\mathrm{Fe}$-oxyhydroxide-rich, red alteration halos in both holes occurred during such open circulation of seawater at low temperatures (probably $<25^{\circ} \mathrm{C}$ ). Despite very small changes in the compositions of circulating seawater, significant amounts of saponite must form in red halos along fractures and in adjacent gray host rocks during this process. The only constraint, to be consistent with observed compositions of basement pore waters (Mottl and Wheat, 1994), is that not enough saponite forms to change the solution compositions significantly (i.e., the amount of seawater reacting with a given volume of rock is very high).

Most saponite in both holes is not associated with Fe-oxyhydroxides, however, and saponite veins typically cut earlier ferric iron bearing phases in veins, vugs, and breccias. Saponite contains predominantly ferrous iron and is commonly associated with secondary pyrite in Holes 504B and 896A, indicating formation under less oxidizing conditions and suggesting more restricted circulation of unaltered seawater. More restricted seawater circulation in ridge-flank systems occurs somewhat farther off-axis, where sediment cover is thicker and outcrops that allow access of seawater to basement are less common (Mottl and Wheat, 1994; Wheat and Mottl, 1994; Alt et al., 1986a; Alt, 1995a). Basement temperatures are higher during such flow, and fluids circulating in the basement are significantly depleted in Mg compared to seawater (Mottl and Wheat, 1994). Consistent with this type of circulation is the formation of pervasive saponite, post-dating the formation of oxidation halos and taking up $\mathrm{Mg}$ from solution into breccia cements and vein fillings (i.e., saponite precipitation causes the $\mathrm{Mg}$ depletion of circulating seawater fluids). Temperatures of formation for saponite in Holes 504B and 896A, estimated from oxygen isotope ratios, range from about $50^{\circ} \mathrm{C}$ up to $130^{\circ} \mathrm{C}$ (Honnorez et al., 1983; J.C. Alt and D.A.H. Teagle, unpubl. data), consistent with present temperatures in the hole that range from $\sim 55^{\circ} \mathrm{C}$ at the basement/sediment interface to about $110^{\circ} \mathrm{C}$ at the base of the lava pile (Becker, Foss, et al., 1992). Sr isotope ratios of saponite veins from Hole 896A indicate generally slightly evolved or partly reacted fluid compositions, but one saponite vein has a nearly basaltic $\mathrm{Sr}$ isotope ratio, suggesting that fluids evolve locally to more rock-dominated, highly reacted compositions, perhaps in regions of much more restricted fluid flow (Teagle et al. this volume).

Conditions throughout the volcanic section of Hole 504B are interpreted to have evolved from more open and oxidizing during formation of the reddish alteration halos, to more restricted circulation of seawater and evolved fluid compositions during formation of late zeolites and carbonates (e.g., low Mg contents of carbonates reflect decreased fluid $\mathrm{Mg} / \mathrm{Ca}$ ratio; Alt et al., 1986a). The temperatures of formation of vein carbonates in the lower volcanic section of Hole $504 \mathrm{~B}$, estimated from oxygen isotope ratios, range from $0^{\circ}$ to $40^{\circ} \mathrm{C}$ for vein carbonates (Honnorez et al., 1983; Alt et al., 1986b). The latter temperatures are lower than the current temperatures in the hole of $\sim 55^{\circ}-110^{\circ} \mathrm{C}$, indicating that the section has been conductively reheated since formation of the vein carbonates.

As in Hole 504B, low Mg contents of vein carbonates from Hole $896 \mathrm{~A}$ indicate decreased fluid $\mathrm{Mg} / \mathrm{Ca}$ ratios, but carbonates from Hole 896A also further document the thermal evolution of Site 896 (Teagle et al., this volume). Vein carbonates have a bimodal distribution of $\delta^{18} \mathrm{O}$ values but relatively uniform ${ }^{87} \mathrm{Sr} /{ }^{86} \mathrm{Sr}$ ratios, which suggests formation under two different thermal regimes $\left(\sim 25^{\circ}-35^{\circ} \mathrm{C}\right.$ and $\sim 50^{\circ}-70^{\circ} \mathrm{C}$ ) rather than as the result of evolution of fluid $\delta^{18} \mathrm{O}$ values via seawater interaction with basement (Teagle et al., this volume). These authors suggest that the carbonates document the thermal and chemical evolution of circulating ridge flank hydrothermal fluids, from cooler, more open circulation like that producing red oxidation halos in the rocks, to warmer, more restricted circulation. Trace element analyses of vein carbonates are consistent with this interpretation. The higher temperature carbonates have higher $\mathrm{Mg}, \mathrm{Fe}$, and $\mathrm{Mn}$ contents than the lower temperature carbonates, consistent with higher temperatures of formation and with more reducing conditions and greater mobilization of $\mathrm{Fe}$ and $\mathrm{Mn}$. Low $\mathrm{Sr}$ contents of the higher temperature carbonates also suggest decreased fluid $\mathrm{Sr} / \mathrm{Ca}$ ratios (Teagle et al., this volume). The similarity of temperatures estimated for the higher temperature carbonates with the current temperatures estimated for the Hole $896 \mathrm{~A}$ basement section $\left(\sim 55^{\circ}-80^{\circ} \mathrm{C}\right)$ suggest that these carbonates could have formed under the current thermal regime in a ridge flank upflow zone at Site 896 (Teagle et al., this volume).

On board JOIDES Resolution during Leg 148, the most obvious differences between cores from Holes 896A and 504B were the greater abundance of carbonate veins and the greater abundances of thick (>2 mm) saponite + carbonate veins in Hole 896A. It was suggested that these veins might be the direct result of ridge flank basement fluids that upwell at Site 896 (Alt, Kinoshita, Stokking, et al., 1993). However, there are apparently no differences in the thermal structure of the uppermost basement or in the composition of basement fluids between the two sites that might cause such differences (Mottl, 1989; Langseth et al., 1988; Fisher et al., 1990, 1994). Differences in the temperatures recorded by carbonates at the two sites may be a sampling artifact because carbonates from the upper $200 \mathrm{~m}$ of Hole 504B have not yet been analyzed for oxygen isotopic compositions. This is the depth interval where most of the carbonate veins occur in the core, and it is where the higher temperature (low $\delta^{18} \mathrm{O}$ ) carbonates occur in Hole 896A. The upper $200 \mathrm{~m}$ also happens to be the zone the with the highest permeability and where ridge flank circulation is thought to occur (Becker, this volume; Fisher et al., 1990, 1994). Therefore, the differences in vein abundances and thicknesses between the two sites may simply reflect local heterogeneities in fracturing of the uppermost crust and in sealing of these fractures with secondary minerals. On a smaller scale, such heterogeneities are observed in Hole 896A: the thicker veins are more common in the upper half of the core $(<325 \mathrm{mbsf})$, and the higher temperature carbonates are mainly restricted to 315-400 mbsf (Alt, Kinoshita, Stokking, et al., 1993; Teagle et al., this volume). The restricted distribution of the higher temperature carbonates has been interpreted to reflect heterogeneities in permeability and its evolution, with early fractures sealed by lower temperature carbonates and later-formed fractures sealed by higher temperature carbonates (Teagle et al., this volume).

\section{Permeability and Permeability Evolution}

Permeability of the upper $200 \mathrm{~m}$ of basement at Site 504 ranges from $10^{-13}$ to $10^{-14} \mathrm{~m}^{2}$, but drops off sharply to values of $\sim 10^{-17}$ below 250 mbsf (Anderson and Zoback, 1982; Anderson, Honnerez, Becker, et al., 1985). The decreased permeability in the deeper volcanic section is caused by cementation of pores and fractures with secondary minerals, mainly phyllosilicates (Pezard, 1990). Packer measurements in Hole 896A on Leg 148 indicate permeabilty values of about $10^{-14} \mathrm{~m}^{2}$ over most of the basement section (233-469 mbsf; Becker, this volume). The uppermost $38 \mathrm{~m}$ of the basement ( $<233 \mathrm{mbsf})$, however, is more permeable by about an order of magnitude. The permeability of the basement in Hole 896A plus the slightly concaveupward temperature profile measured shortly after drilling during Leg 148 suggest that seawater was flowing at a modest rate down the casing and into basement (Becker, this volume; Alt, Kinoshita, Stokking, et al., 1993). Similarly, bottom seawater flows down Hole 504B 
and out into the uppermost 100-200 $\mathrm{m}$ of basement (Anderson and Zoback, 1982). This flow of seawater into Hole 504B basement has varied significantly in intensity over 13 years of observation (Becker, Foss, et al., 1992; Dick, Erzinger, Stokking, et al., 1992; Alt, Kinoshita, Stokking, et al., 1993).

The permeabilty of the upper basement in Hole $896 \mathrm{~A}$ is similar to that in Hole 504B, suggesting that the upper $\sim 200 \mathrm{~m}$ of basement is sufficiently permeable on a regional scale to support circulation in ridge flank basement (Fisher et al., 1990, 1994; Becker, this volume). Upper basement permeability measured at other DSDP/ODP sites on ridge flanks and farther off-axis is similar to that at Sites 504 and 896, indicating that values of $10^{-14}$ to $10^{-13} \mathrm{~m}^{2}$, may be fairly typical of the upper ocean crust on ridge flanks (Becker, this volume).

Independent estimates of upper crustal permeability can be made by using the measurements of vein spacings and widths in cores from Holes 504B and 896A. Such estimates can provide constraints on permeability of uncemented crust, such as might be present in very young crust at spreading axes. Norton and Knapp (1977) gave a model that assumes infinite planar fractures in an ideal system and does not take into account fracture continuity, tortuosity, or wall roughness. In this model, permeability $(K)$ is a function only of fracture spacing $(n)$ and aperture $(d)$, where $K=n d^{3} / 12$. Using fracture spacings of $0.12-0.48$ veins $/ \mathrm{cm}$ and an average fracture width of $0.03 \mathrm{~cm}$ (the range and average, respectively, for Holes 504B and 896A; Alt, Kinoshita, Stokking, et al., 1993; J.C. Alt and D.A.H. Teagle, unpubl. data), gives flow permeability estimates of $0.3-1.1 \times 10^{-10} \mathrm{~m}^{2}$. These values exceed those measured in ridge flanks by two orders of magnitude. This must be in part because not all the veins measured in the drill core were open at the same time, and many of the veins measured in the core are probably not laterally continuous (Alt, Kinoshita, Stokking, et al., 1993). Although the permeabilty values calculated here are high, similar values have been measured in a borehole in Middle Valley on the Juan de Fuca Ridge (Becker et al., 1994). One basement hole there had a permeabilty value of $10^{-14} \mathrm{~m}^{2}$, but another hole contained zones that had apparent permeability values on the order of $10^{-10} \mathrm{~m}^{2}$ (Becker et al., 1994).

Calculations of permeability similar to those made here were made by Johnson (1979) for Hole 418A in 110 Ma old crust in the Atlantic. The abundance of filled veins in that core is only about onehalf that measured for the volcanic sections of Holes 504B and 896A ( $\sim 14$ vs. $~ 30$ veins $/ \mathrm{m}$, respectively), but the average width of veins in Hole 418A is an order of magnitude larger than that for the other two holes ( 2 vs. $0.3 \mathrm{~mm}$; Johnson, 1979; J.C. Alt and D.A.H. Teagle, unpubl. data). Using estimates for the abundance of filled fractures in Hole 418A, Johnson's (1979) data yield a permeability of $9 \times 10^{-9} \mathrm{~m}^{2}$, 2 orders of magnitude greater than that calculated here for Holes 504B and 896A. This discrepancy may be in part the result of continued opening and filling of fractures, which were not all open at the same time. Eliminating late-stage carbonate veins from the calculation decreases the permeability, but only by one-half, to $5 \times 10^{-9} \mathrm{~m}^{2}$, still two orders of magnitude greater than calculated for core from Holes 504B and 896A, and 4-5 orders of magnitude greater than measured for the uppermost ocean crust in situ (Becker, this volume). Other effects that are not taken into account in the vein calculations, such as tortuosity and vein length and connectivity, probably contribute to the higher calculated permeability measurements; however, real differences in fracturing and permeability must exist within the uppermost crust.

There is abundant evidence in drill cores that upper crustal permeability evolves with time. Crosscutting veins indicate that fractures seal and then are reopened or new fractures are created. Fibrous saponite \pm carbonate veins in Hole $896 \mathrm{~A}$ are interpreted to have formed by the crack-seal mechanism, implying fluid overpressures (Harper and Tartarotti, this volume; Tartarotti et al., this volume). Fibrous veins are generally late-stage, presumably forming after sealing of other fractures by deposition of minerals in non fibrous veins, which would have decreased permeability and allowed fluid pressures to increase. Similar fibrous veins are common in Hole 504B and in other oceanic basement cores (J.C. Alt and D.A.H. Teagle, unpubl. data; Alt and Honnorez, 1984), suggesting that if such veins really result from fluid overpressures, then overpressures must be common in ridge flank basement fluids.

Many of the breccias in Hole 896A are late features, post-dating the formation of oxidation halos in the rocks as indicated by truncation of veins and red oxidation halos in breccia clasts (Alt, Kinoshita, Stokking, et al., 1993). Although difficult to prove because of the general lack of preservation of the contacts with the surrounding rocks, these breccias are consistent with origins through extensional faulting (Harper and Tartarotti, this volume). Other evidence for faulting at Site 896 includes a change in stable magnetic inclination below $\sim 350$ mbsf, shear along fractures and veins below $334 \mathrm{mbsf}$, and abundant fracturing at $\sim 350 \mathrm{mbsf}$ indicated by electrical logs (Alt, Kinoshita, Stokking, et al., 1993; Allerton et al., this volume; de Larouzière et al., this volume). Such faulting would certainly affect local permeability, possibly providing paths for focusing of fluid flow. Permeability measurements of upper ocean crust, modeling of fluid flow in ridge flank systems, and extreme alteration effects in breccia zones suggest that much of the flow in ridge flank circulation systems may take place along such discrete high-permeability layers (Larson et al., 1993; Fisher et al., 1990, 1994; Muehlenbachs, 1980; Pezard, 1990). Because of the large aspect ratio of convection cells around Sites 504 and 896 (Fisher et al., 1990, 1994), however, horizontal high-permeability zones (e.g., seafloor breccias, fractured pillow flows) may be more important than subvertically oriented extensional fault zones in providing pathways for focusing fluid flow.

\section{Quantification of Alteration Effects in the Crust}

The measured abundances of different alteration types and vein minerals in the two drill cores can be used to quantify chemical changes that take place during alteration of volcanic rocks and cementation of basement with secondary minerals. Figure 14 illustrates major element chemical changes in Holes 504B and 896A. The upper volcanic section of Hole 504B reflects alteration similar to that in Hole 896A, and both sections exhibit consistent gains of $\mathrm{Si}, \mathrm{Mg}, \mathrm{Fe}^{\mathrm{T}}$, $\mathrm{K}, \mathrm{H}_{2} \mathrm{O}$, and $\mathrm{CO}_{2}$. Many elements (e.g., $\mathrm{Mg}$ and $\mathrm{Ca}$ ) are actually lost from altered rocks in the upper volcanic section, but are retained or gained by the crust in veins and breccia cements (e.g., in saponite and carbonate). Chemical changes in the lower volcanic section of Hole 504B are generally much smaller in magnitude than those in the upper volcanic sections.

The estimates of chemical change for Hole 504B in Figure 14 are much smaller than previous estimates for this section (Alt et al., 1986a). This is because the measured amounts of secondary minerals cementing the section are smaller than the rough estimates used by Alt et al. (1986a). Figure 15 shows the annual river fluxes of $\mathrm{Mg}, \mathrm{Ca}$, $\mathrm{Si}$, and $\mathrm{K}$ to the oceans for comparison. The chemical changes in Figure 13 are only a small fraction (a few percent) of the river fluxes.

The settings of Holes 504B and 896A in areas of horizontal and upwelling flow, respectively, of ridge flank hydrothermal fluids are nearly identical to those of two holes drilled in $110 \mathrm{Ma}$ crust in the Atlantic. Hole 417D penetrates $365 \mathrm{~m}$ into basement and Hole 417A, $450 \mathrm{~m}$ away, penetrates $217 \mathrm{~m}$ into a $\sim 200$-m-relief basement hill that was a site of upwelling ridge flank hydrothermal fluids (Donnelly, Francheteau, Bryan, Robinson, Flower, Salisbury, et al., 1979). Despite the much greater age of the rocks, alteration of basement from Hole 417D is quite similar to that in Holes 504B and 896A, with the exception of several zones in Hole 417D that are highly enriched in $\mathrm{K}_{2} \mathrm{O}$ and ${ }^{18} \mathrm{O}$ (Donnelly, Francheteau, Bryan, Robinson, Flower, Salisbury, et al., 1979; Alt and Honnorez, 1984). In contrast, however, alteration in Hole 417A is probably the most intense in any DSDP/ 

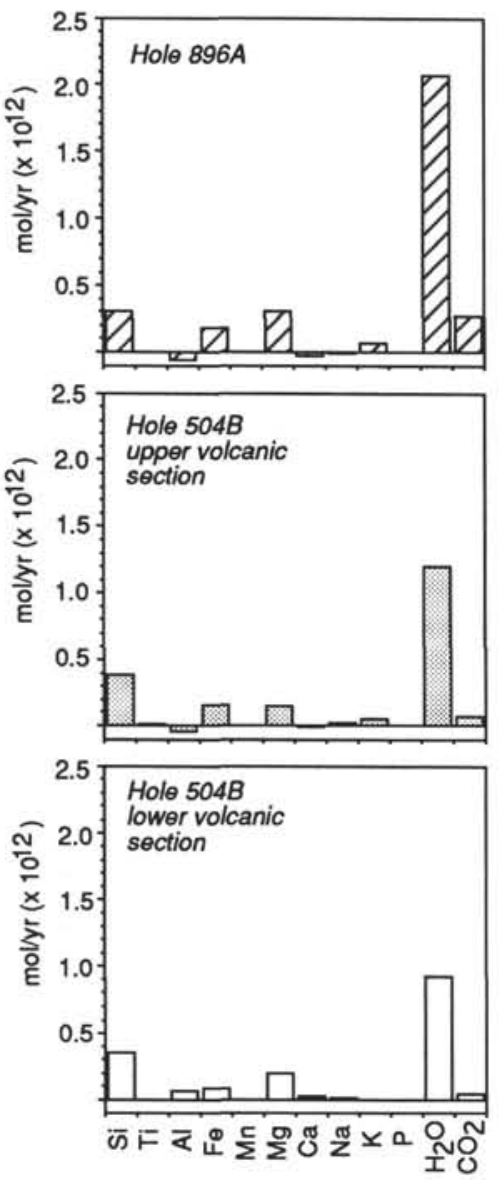

Figure 14. Bar graphs showing chemical changes resulting from alteration of the volcanic sections penetrated by Holes 504B and 896A. Changes are given as average altered crust relative to the average least altered rock. Least altered rocks were taken as those analyses lacking alteration halos and containing less than $0.05 \% \mathrm{~K}_{2} \mathrm{O}$ (these samples also have the lowest $\mathrm{H}_{2} \mathrm{O}$ contents and $\mathrm{Fe}^{3+} / \mathrm{Fe}^{\mathrm{T}}$ ratios). Unaltered $\mathrm{H}_{2} \mathrm{O}$ and $\mathrm{CO}_{2}$ contents were assumed to be $0.2 \%$ and $0.07 \%$, respectively. Average altered crust was calculated from proportions of dark gray rocks, black and red alteration halos, and secondary minerals in veins and breccias given in the text, plus the average compositions of the different rock types from data in Teagle et al. (this volume) and Alt et al. (1986a) and compositions of secondary minerals. Average compositions of saponites from each section were calculated from data given by Teagle et al. (this volume), Alt et al. (1986a), and J.C. Alt and D.A.H. Teagle (unpubl. data); saponite density was taken as $2.5 \mathrm{~g} / \mathrm{cm}^{3}$. Calcite was assumed to be pure $\mathrm{CaCO}_{3}$ with a density of 2.7. Celadonite abundance in veins of Hole 504B was taken as $0.008 \%$ of the section (J.C. Alt and D.A.H. Teagle, unpubl. data). The composition of celadonite is from Alt (1984); it has a density of 2.5 . The density values of all rocks were assumed to be $2.9 \mathrm{~g} / \mathrm{cm}^{3}$. Changes are given as global fluxes, assuming $3 \mathrm{~km}^{2}$ crust generated per year and given thicknesses of $300 \mathrm{~m}$ each for the upper volcanic section of Hole $504 \mathrm{~B}$ and for the Hole $896 \mathrm{~A}$ section, and $250 \mathrm{~m}$ for the lower Hole 504B volcanic section.

ODP basement core, with highly oxidized, alkali-enriched, and $\mathrm{Mg}$ depleted rocks (e.g., common $\mathrm{K}$-feldspar, whole-rock $\mathrm{K}_{2} \mathrm{O}$ contents up to $9 \%$; Donnelly, Francheteau, Bryan, Robinson, Flower, Salisbury, et al., 1979; Alt and Honnorez, 1984). The hill penetrated by Hole $417 \mathrm{~A}$ remained uncovered by sediment for up to $\sim 20 \mathrm{Ma}$, which may have allowed focusing of larger amounts of fluid outflow for a much longer time than at Site 896. The upward increase of the extreme oxidation and K-enrichment in Hole 417A suggest that bottom
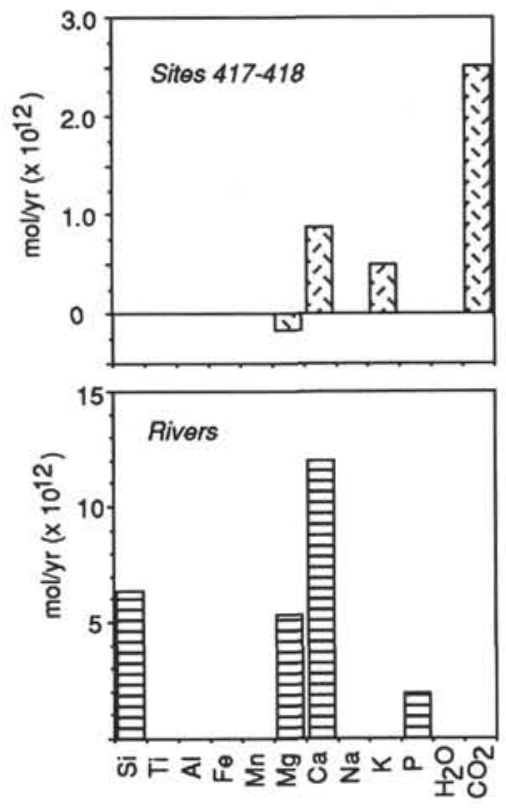

Figure 15. Bar graphs showing annual river fluxes to the oceans (after Thompson, 1983), and chemical fluxes from the upper $500 \mathrm{~m}$ of altered crust based on rock composites from DSDP Sites 417 and 418 (and assuming 3 $\mathrm{km}^{2}$ crustal production per year; Spivack and Staudigel, 1994; Staudigel et al., 1989). Ca flux includes $\mathrm{Ca}$ in $\mathrm{CaCO}_{3}$ in altered crust.

seawater may have been entrained into the exposed hill, further enhancing alteration, whereas the fluids circulating through basement at Site 896 are more reacted and partly equilibrated with basalt (Mottl, 1989).

Geochemical fluxes based on composites of the altered volcanic section from DSDP Site 417 and nearby Site 418 are shown in Figure 14. The loss of $\mathrm{Mg}$ from the crust in this estimate is insignificant within the errors of the calculations (Spivack and Staudigel, 1994). Nevertheless, the lack of $\mathrm{Mg}$ gain by the crust is somewhat surprising given that it is estimated that the $536 \mathrm{~m}$ section of Hole $418 \mathrm{~A}$ contains $10 \% \mathrm{Mg}$-rich smectite in veins and breccias, compared to $2.5 \%$ in Hole $896 \mathrm{~A}$ and $1.7 \%$ in Hole 504B (J.C. Alt and D.A.H. Teagle, unpubl. data; Johnson, 1979; Staudigel and Hart, 1983). The Hole $418 \mathrm{~A}$ estimate assumes that breccias contain $40 \%$ matrix rather than the $10 \%$ average for Hole 504B, but the amount of smectite in veins of Hole $418 \mathrm{~A}$ is $7.1 \%$, still $1-2$ orders of magnitude greater than in Holes 504B and 896A (Fig. 11; Johnson, 1979; Staudigel and Hart, 1983). This large difference reflects the much wider veins in Hole $418 \mathrm{~A}$ than in Holes 504B and 896A (mean values of $2 \mathrm{~mm}$ and 0.3 $\mathrm{mm}$, respectively). The Site $417-418$ estimates in Figure 14 are significantly affected by inclusion of the extremely altered rocks from Hole 417A, which have experienced extensive loss of Mg (Donnelly, Francheteau, Bryan, Robinson, Flower, Salisbury, et al., 1979; Alt and Honnorez, 1984; Spivack and Staudigel, 1994).

The K uptake from Sites $417-418$ amounts to about $50 \%$ of the river flux, substantially greater than for Sites 504-896 (Figs. 13, 14). This is because the Site $417-418$ estimates assume that highly altered rocks like the basement hill penetrated by Hole 417A make up $20 \%$ of the uppermost ocean crust (Spivack and Staudigel, 1994). This sort of extremely altered rock may be important for geochemical budgets (Donnelly, Francheteau, Bryan, Robinson, Flower, Salisbury, et al., 1979), but the amount of oceanic crust affected in this way is not really known.

The calculated $\mathrm{CO}_{2}$ uptake by Sites $417-418$ (Fig. 15) is an order of magnitude greater than that in Figure 14. The amount of carbonate 
contained in veins and breccias of Hole $418 \mathrm{~A}$ ( $8 \%$ of the core) is an order of magnitude greater than in Hole $896 \mathrm{~A}(0.4 \%)$ and two orders of magnitude greater than in Hole 504B $(0.04 \%$; J.C. Alt and D.A.H Teagle, unpubl. data; Johnson, 1979; Staudigel and Hart, 1983). Staudigel et al. (1981) suggested that the $\mathrm{CO}_{2}$ content of older crust increases as the crust "ages." These authors based this inference on the higher $\mathrm{CO}_{2}$ contents of $110 \mathrm{Ma}$ old rocks from Hole $418 \mathrm{~A}$ compared to those of $3.2 \mathrm{Ma}$ Hole $332 \mathrm{~B}$ in the Atlantic. Multiple generations of late carbonate veins are present in old oceanic volcanic rocks, and similar increases in $\mathrm{CO}_{2}$ content with age have been suggested for Pacific crust (Alt and Honnorez, 1984; Alt et al., 1992; Alt, 1993). The data for Holes 504B and 896A indicate significant $(2 \times)$ variation in the $\mathrm{CO}_{2}$ content of crust having nearly identical ages (Fig. 14). This suggests heterogeneity in the $\mathrm{CO}_{2}$ content of the crust, and that additional quantitative data are needed to confirm estimates of $\mathrm{CO}_{2}$ uptake and variations with age.

\section{SUMMARY AND CONCLUSIONS}

Hole 504B is sited on the back side of a tilted basement block, whereas Hole $896 \mathrm{~A}$ is located $\sim 1 \mathrm{~km}$ away, on the top of a basement high that coincides with high heat flow and upwelling fluids. Hole $504 \mathrm{~B}$ penetrates through $274.5 \mathrm{~m}$ of sediment and the $571.5-\mathrm{m}$ volcanic section, to $2111 \mathrm{mbsf}$ in sheeted dikes. Hole $896 \mathrm{~A}$ penetrates $179 \mathrm{~m}$ sediment and $290 \mathrm{~m}$ into volcanic basement, to $469 \mathrm{mbsf}$. Core recovery was similar for the two volcanic sections $(26.9 \%-29.8 \%)$, and there are no simple relationships between core recovery and abundance of veins or proportions of breccia or massive basalts in the recovered cores. Subtle differences in lithostratigraphy between the two sections include slightly greater proportions of massive units and a smaller proportion of pillow basalts in Hole 896A compared to Hole 504B. Breccias are similar in abundance in Hole 896 A (8\%) and in the analogous upper $300 \mathrm{~m}$ of the Hole 504B section (6\%), but they are much more common in the lower volcanic section of Hole 504B (19\%). Although the two sections are geochemically quite similar, there is no direct correlation of lithologic or geochemical units between the two sites. Paleomagnetic results suggest tilting of both sections during crustal accretion. Veins are similar in abundance in the two volcanic sections $(~ 30$ veins $/ \mathrm{m}$, mean vein width $<1 \mathrm{~mm})$, but carbonate veins and thick ( $>2 \mathrm{~mm})$ saponite and carbonate veins are more common in Hole 896A than in Hole 504B.

Permeability values of the upper basement in Holes 896A and 504B are similar $\left(\sim 10^{-13}\right.$ to $\left.10^{-14} \mathrm{~m}^{2}\right)$, suggesting that the upper $\sim 200$ $\mathrm{m}$ of basement is sufficiently permeable on a regional scale to support circulation in ridge flank basement. This permeability is also similar to that measured at other DSDP/ODP sites, indicating that this may be fairly typical of the upper ocean crust on ridge flanks.

Alteration effects in basement from Hole 896A are generally very similar to those in the upper $320 \mathrm{~m}$ of volcanic rocks in Hole 504B. Early celadonitic phyllosilicates formed in small amounts in fractures and in alteration halos in the rocks around veins in these two sections. Subsequently, red alteration halos developed along fractures, with the formation of abundant Fe-oxyhydroxides and common saponite in the rocks as the result of open circulation of large volumes of cold, oxidizing seawater. Following this, saponite \pm carbonate formed in rocks, veins, and cementing breccias throughout Hole 896A and the entire volcanic section of Hole 504B during more restricted circulation of seawater. Finally, late-stage carbonates and minor zeolites formed in veins throughout both holes, from reacted seawater fluids (decreased fluid $\mathrm{Mg} / \mathrm{Ca}$ as the result of saponite formation).

Oxygen and strontium isotopic data are interpreted to reflect the formation of two generations of carbonate veins in Hole 896A. Earlier carbonates formed at relatively low temperatures during more open circulation of seawater, whereas later carbonates formed at slightly higher temperatures during more restricted circulation of sea- water, possibly similar to the present conditions of hydrothermal upflow $\left(\mathrm{T}=50^{\circ}-80^{\circ} \mathrm{C}\right)$. The compositions and temperatures inferred for fluids circulating in basement at Sites 504 and 896 are similar, so it is unlikely that there are any chemical effects in the rocks that would distinguish their different positions within a circulation cell. The greater abundance of thick saponite and carbonate veins in Hole $896 \mathrm{~A}$ than in Hole 504B is attributed to heterogeneities in fracturing and permeability evolution.

Chemical changes in altered upper crust include increased $\mathrm{Mg}, \mathrm{K}$, $\mathrm{Rb}, \mathrm{B}, \mathrm{Cs}, \mathrm{Li}, \mathrm{CO}_{2}$, and $\mathrm{H}_{2} \mathrm{O}$ contents; local uptake of $\mathrm{P}_{2} \mathrm{O}_{5}$; elevated $\delta^{18} \mathrm{O}, \delta \mathrm{D}, \delta^{11} \mathrm{~B},{ }^{87} \mathrm{Sr} /{ }^{86} \mathrm{Sr}$, and $\mathrm{Fe}^{3+} / \mathrm{Fe}^{\mathrm{T}}$; and lower $\mathrm{S}$ contents and $\delta^{34} \mathrm{~S}$. The largest chemical changes occur in alteration halos and breccias, and the smallest changes occur in the lower volcanic section of Hole 504B. Secondary minerals in veins and breccias are important sites of mass and isotopic exchange between seawater and the crust.

\section{ACKNOWLEDGMENTS}

This work was supported by grants from JOI-USSAC to Alt and Teagle, by NSF Grant nos. OCE-9217423 and OCE-9314218 to Alt, and by grants from CNRS-INSU to Honnorez and Laverne. We thank Lori Bettison-Varga and Geoff Wheat for helpful reviews.

\section{REFERENCES}

Adamson, A.C., 1985. Basement lithostratigraphy, Deep Sea Drilling Project Hole 504B. In Anderson, R.N., Honnorez, J., Becker, K., et al., Init. Repts. DSDP, 83: Washington (U.S. Govt. Printing Office), 121-127.

Adamson, A.C., and Richards, H.G., 1990. Low-temperature alteration of very young basalts from ODP Hole 648B: Serocki Volcano, Mid-Atlantic Ridge. In Detrick, R., Honnorez, J., Bryan, W.B., Juteau, T., et al., Proc. ODP, Sci. Results, 106/109: College Station, TX (Ocean Drilling Program), 181-194.

Alt, J.C., 1984. The structure, chemistry, and evolution of a submarine hydrothermal system, DSDP Site 504 [Ph.D. dissert.]. Univ. Miami, FL.

, 1993. Low-temperature alteration of basalts from the Hawaiian Arch, Leg 136. In Wilkens, R.H., Firth, J.V., Bender, J., et al., Proc. ODP, Sci. Results, 136: College Station, TX (Ocean Drilling Program), 133-146.

_ 1995a. Subseafloor processes in mid-ocean ridge hydrothermal systems. In Humphris, S., Lupton, J., Mullineaux, L., and Zierenberg, R. (Eds.), Physical, Chemical, and Biological Interactions within Submarine Hydrothermal Systems. Geophys. Monogr., Am. Geophys. Union., 91:85-114.

$-1995 \mathrm{~b}$. Sulfur isotopic profile through the oceanic crust: sulfur mobility and seawater-crustal sulfur exchange during hydrothermal alteration. Geology, 23:585-588.

Alt, J.C., France-Lanord, C., Floyd, P.A., Castillo, P., and Galy, A., 1992. Low-temperature hydrothermal alteration of Jurassic ocean crust, Site 801. In Larson, R.L., Lancelot, Y., et al., Proc. ODP, Sci. Results, 129: College Station, TX (Ocean Drilling Program), 415-427.

Alt, J.C., and Honnorez, J., 1984. Alteration of the upper oceanic crust, DSDP Site 417: mineralogy and chemistry. Contrib. Mineral. Petrol., 87:149-169.

Alt, J.C., Honnorez, J., Laverne, C., and Emmermann, R., 1986a. Hydrothermal alteration of a $1 \mathrm{~km}$ section through the upper oceanic crust, Deep Sea Drilling Project Hole 504B: mineralogy, chemistry, and evolution of seawater-basalt interactions. J. Geophys. Res., 91:10309-10335.

Alt, J.C., Kinoshita, H., Stokking, L.B., et al., 1993. Proc. ODP, Init. Repts., 148: College Station, TX (Ocean Drilling Program).

Alt, J.C., Muehlenbachs, K., and Honnorez, J., 1986b. An oxygen isotopic profile through the upper kilometer of the oceanic crust, DSDP Hole 504B. Earth Planet. Sci. Lett., 80:217-229.

Anderson, R.N., Honnorez, J., Becker, K., et al., 1985. Init. Repts. DSDP, 83: Washington (U.S. Govt. Printing Office).

Anderson, R.N., and Zoback, M.D., 1982. Permeability, underpressures, and convection in the oceanic crust near the Costa Rica Rift, eastern equatorial Pacific. J. Geophys. Res., 87:2860-2868.

Aumento, F., Melson, W.G., et al., 1977. Init. Repts. DSDP, 37: Washington (U.S. Govt. Printing Office). 
Autio, L.K., and Rhodes, J.M., 1983. Costa Rica Rift Zone basalts: geochemical and experimental data from a possible example of multistage melting. In Cann, J.R., Langseth, M.G., Honnorez, J., Von Herzen, R.P. White, S.M., et al., Init. Repts. DSDP, 69: Washington (U.S. Govt. Printing Office), 729-745.

Barrett, T.J., 1983. Strontium- and lead-isotope composition of some basalts from Deep Sea Drilling Project Hole 504B, Costa Rica Rift, Legs 69 and 70. In Cann, J.R., Langseth, M.G., Honnorez, J., Von Herzen, R.P., White, S.M., et al., Init. Repts. DSDP, 69: Washington (U.S. Govt. Printing Office), 643-650.

Barrett, T.J., and Friedrichsen, H., 1982. Strontium and oxygen isotopic composition of some basalts from Hole 504B, Costa Rica Rift, DSDP Legs 69 and 70. Earth Planet. Sci. Lett., 60:27-38.

Becker, K., 1989. Measurements of the permeability of the sheeted dikes in Hole 504B, ODP Leg 111. In Becker, K., Sakai, H., et al., Proc. ODP. Sci. Results, 111: College Station, TX (Ocean Drilling Program), $317-$ 325.

Becker, K., Foss, G., et al., 1992. Proc. ODP, Init. Repts., 137: College Station, TX (Ocean Drilling Program).

Becker, K., Morin, R.H., and Davis, E.E., 1994. Permeabilities in the Middle Valley hydrothermal system measured with packer and flowmeter experiments. In Mottl, M.J., Davis, E.E., Fisher, A.T., and Slack, J.F. (Eds.), Proc. ODP, Sci. Results, 139: College Station, TX (Ocean Drilling Program), 613-626.

Becker, K., Sakai, H., et al., 1988. Proc. ODP, Init. Repts., 111: College Station, TX (Ocean Drilling Program).

Böhlke, J.K., Alt, J.C., and Muehlenbachs, K., 1984. Oxygen isotope-water relations in altered deep-sea basalts: low temperature mineralogical controls. Can. J. Earth Sci., 21:67-77.

Böhkle, J.K., Honnorez, J., and Honnorez-Guerstein, B.M., 1980. Alteration of basalts from site 396B, DSDP: petrographic and mineralogical studies. Contrib. Mineral. Petrol., 73:341-364.

Brewer, T.S., Harvey, P.K., Lovell, M.A., and Williamson, G., 1995. Stratigraphy of the ocean crust in ODP Hole 896A from FMS images. Sci Drill., 5:87-92.

Bryan, W.B., Thompson, G., Frey, F.A., and Dickey, J.S., 1976. Inferred settings and differentiation in basalts from the Deep Sea Drilling Project. $J$. Geophys. Res., 81:4285-4304.

Cande, S.C., and Kent, D.V., 1995. Revised calibration of the geomagnetic polarity timescale for the Late Cretaceous and Cenozoic. J. Geophys. Res., 100:6093-6095.

Cann, J.R., Langseth, M.G., Honnorez, J., Von Herzen, R.P., White, S.M., et al., 1983. Init. Repts. DSDP, 69: Washington (U.S. Govt. Printing Office).

Dick, H.J.B., Erzinger, J., Stokking, L.B., et al., 1992. Proc. ODP, Init. Repts., 140: College Station, TX (Ocean Drilling Program).

Dmitriev, L., Heirtzler, J., et al., 1979. Init. Repts. DSDP, 46: Washington (U.S. Govt. Printing Office).

Donnelly, T., Francheteau, J., Bryan, W., Robinson, P., Flower, M., Salisbury, M., et al., 1980. Init. Repts. DSDP, 51, 52, 53 (Pts. 1 and 2): Washington (U.S. Govt. Printing Office).

Emmermann, R., 1985. Basement geochemistry, Hole 504B. In Anderson, R.N., Honnorez, J., Becker, K., et al., Init. Repts. DSDP, 83: Washington (U.S. Govt. Printing Office), 183-199.

Etoubleau, J., Corre, O., Joron, J.L., Bougault, H., and Treuil, M., 1983. Costa Rica Rift: variably depleted basalts in the same hole. In Cann, J.R., Langseth, M.G., Honnorez, J., Von Herzen, R.P., White, S.M., et al., Init. Repts. DSDP, 69: Washington (U.S. Govt. Printing Office), 765-773.

Fisher, A.T., Becker, K., and Narasimhan, T.N., 1994. Off-axis hydrothermal circulation: parametric tests of a refined model of processes at Deep Sea Drilling Project/Ocean Drilling Program site 504. J. Geophys. Res., 99:3097-3123.

Fisher, A.T., Becker, K., Narasimhan, T.N., Langseth, M.G., and Mottl, M.J., 1990. Passive off-axis convection through the southern flank of the Costa Rica Rift. J. Geophys. Res., 95:9343-9370.

Furuta, T., and Levi, S., 1983. Basement paleomagnetism of Hole 504B. In Cann, J.R., Langseth, M.G., Honnorez, J., Von Herzen, R.P., White, S.M., et al., Init. Repts. DSDP, 69: Washington (U.S. Govt. Printing Office), 697-703.

Hey, R., Johnson, G.L., and Lowrie, A., 1977. Recent plate motions in the Galapagos area. Geol. Soc. Am. Bull., 88:1385-1403.

Hobart, M.A., Langseth, M.G., and Anderson, R.N., 1985. A geothermal and geophysical survey on the south flank of the Costa Rica Rift: Sites 504 and 505. In Anderson, R.N., Honnorez, J., Becker, K., et al., Init. Repts. DSDP, 83: Washington (U.S. Govt. Printing Office), 379-404.

Honnorez, J., Alt, J.C., Honnorez-Guerstein, B.-M., Laverne, C., Muehlenbachs, K., Ruiz, J., and Saltzman, E., 1985. Stockwork-like sulfide mineralization in young oceanic crust: Deep Sea Drilling Project Hole 504B In Anderson, R.N., Honnorez, J., Becker, K., et al., Init. Repts. DSDP, 83: Washington (U.S. Govt. Printing Office), 263-282.

Honnorez, J., Laverne, C., Hubberten, H.-W., Emmermann, R., and Muehlenbachs, K., 1983. Alteration processes in Layer 2 basalts from Deep Sea Drilling Project Hole 504B, Costa Rica Rift. In Cann, J.R., Langseth, M.G., Honnorez, J., Von Herzen, R.P., White, S.M., et al., Init. Repts. DSDP, 69: Washington (U.S. Govt. Printing Office), 509-546.

Hubberten, H.-W., Emmermann, R., and Puchelt, H., 1983. Geochemistry of basalts from Costa Rica Rift Sites 504 and 505 (Deep Sea Drilling Project Legs 69 and 70). In Cann, J.R., Langseth, M.G., Honnorez, J. Von Herzen, R.P., White, S.M., et al., Init. Repts. DSDP, 69: Washington (U.S. Govt. Printing Office), 791-803.

Ishikawa, T., and Nakamura, E., 1992. Boron isotope geochemistry of the oceanic crust from DSDP/ODP Hole 504B. Geochim. Cosmochim. Acta, $56: 1633-1639$

Johnson, D.M., 1979. Crack distribution in the upper oceanic crust and its effects upon seismic velocity, seismic structure, formation permeability, and fluid circulation. In Donnelly, T., Francheteau, J., Bryan, W., Robinson, P., Flower, M., Salisbury, M., et al., Init. Repts. DSDP, 51, 52, 53 (Pt. 2): Washington (U.S. Govt. Printing Office), 1479-1490.

Kempton, P.D., Autio, L.K., Rhodes, J.M., Holdaway, M.J., Dungan, M.A. and Johnson, P., 1985. Petrology of basalts from Hole 504B, Deep Sea Drilling Project, Leg 83. In Anderson, R.N., Honnorez, J., Becker, K., et al., Init. Repts. DSDP, 83: Washington (U.S. Govt. Printing Office), 129-164.

Langseth, M.G., Cann, J.R., Natland, J.H., and Hobart, M., 1983. Geothermal phenomena at the Costa Rica Rift: background and objectives for drilling at Deep Sea Drilling Project Sites 501, 504, and 505. In Cann, J.R., Langseth, M.G., Honnorez, J., Von Herzen, R.P., White, S.M., et al., Init. Repts. DSDP, 69: Washington (U.S. Govt. Printing Office), 529.

Langseth, M.G., Mottl, M.J., Hobart, M.A., and Fisher, A., 1988. The distribution of geothermal and geochemical gradients near Site 501/504: implications for hydrothermal circulation in the oceanic crust. In Becker, K., Sakai, H., et al., Proc. ODP, Init. Repts., 111: College Station, TX (Ocean Drilling Program), 23-32.

Larson, R.L., Fisher, A.T., Jarrard, R.D., Becker, K., et al., 1993. Highly permeable and layered Jurassic oceanic crust in the western Pacific. Earth Planet. Sci. Lett., 119:71-83.

Laverne, C., 1987. Les altérations des basaltes en domaine océanique: minéralogie, pétrologie et géochimie d'un système hydrothermal: le puits 504B, Pacifique oriental [Thèse]. Univ. Aix-Marseille III.

Laverne, C., and Vivier, G., 1983. Petrographical and chemical study of basement from the Galapagos Spreading Center, Leg 70. In Honnorez, J. Von Herzen, R.P., et al., Init. Repts. DSDP, 70: Washington (U.S. Govt. Printing Office), 375-390.

Melson, W.G., Rabinowitz, P.D., et al., 1979. Init. Repts. DSDP, 45: Washington (U.S. Govt. Printing Office).

Mottl, M.J., 1989. Hydrothermal convection, reaction, and diffusion in sediments on the Costa Rica Rift flank: pore-water evidence from ODP Sites 677 and 678. In Becker, K., Sakai, H., et al., Proc. ODP, Sci. Results, 111: College Station, TX (Ocean Drilling Program), 195-213.

Mottl, M.J., Lawrence, J.R., and Keigwin, L.D., 1983. Elemental and stableisotope composition of pore waters and carbonate sediments from Deep Sea Drilling Project Sites 501/504 and 505. In Cann, J.R., Langseth, M.G., Honnorez, J., Von Herzen, R.P., White, S.M., et al., Init. Repts. DSDP, 69: Washington (U.S. Govt. Printing Office), 461-473.

Mottl, M.J., and Wheat, C.G., 1994. Hydrothermal circulation through midocean ridge flanks: fluxes of heat and magnesium. Geochim. Cosmochim. Acta, 58:2225-2238.

Muehlenbachs, K., 1980. The alteration and aging of the basaltic layer of the sea floor: oxygen isotope evidence from DSDP/IPOD Legs 51, 52, and 53. In Donnelly, T., Francheteau, J., Bryan, W., Robinson, P., Flower, M., Salisbury, M., et al., Init. Repts. DSDP, 51, 52, 53 (Pt. 2): Washington (U.S. Govt. Printing Office), 1159-1167.

Natland, J.H., 1979. Comparison of chemical and magnetic stratigraphy of Holes 396 and 396B. In Dmitriev, L., Heirtzler, J., et al., Init. Repts. DSDP, 46: Washington (U.S. Govt. Printing Office), 425-430. 
Natland, J.H., Adamson, A.C., Laverne, C., Melson, W.G., and O'Hearn, T., 1983. A compositionally nearly steady-state magma chamber at the Costa Rica Rift: evidence from basalt glass and mineral data, Deep Sea Drilling Project Sites 501, 504, and 505. In Cann, J.R., Langseth, M.G. Honnorez, J., Von Herzen, R.P., White, S.M., et al., Init. Repts. DSDP, 69: Washington (U.S. Govt. Printing Office), 811-858.

Noack, Y., Emmermann, R., and Hubberten, H.-W., 1983. Alteration in Site 501 (Leg 68) and Site 504 (Leg 69) basalts: preliminary results. In Cann, J.R., Langseth, M.G., Honnorez, J., Von Herzen, R.P., White, S.M., et al., Init. Repts. DSDP, 69: Washington (U.S. Govt. Printing Office), 497-508.

Norton, D., and Knapp, R., 1977. Transport phenomena in hydrothermal systems: the nature of porosity. Am. J. Sci., 277:913-936.

Parsons, B., and Sclater, J.G., 1977. An analysis of the variation of ocean floor bathymetry and heat flow with age. J. Geophys. Res., 82:803-829.

Pezard, P.A., 1990. Electrical properties of mid-ocean ridge basalt and implications for the structure of the upper oceanic crust in Hole 504B. J, Geophys. Res., 95:9237-9264.

Spivak, A.J., and Staudigel, H., 1994. Low temperature alteration of the upper oceanic crust and the alkalinity budget of seawater. Chem. Geol., 115: 239-247.
Staudigel, H., and Hart, S.R., 1983. Alteration of basaltic glass: mechanisms and significance for the oceanic crust-seawater budget. Geochim. Cosmochim. Acta, 47:337-350.

Staudigel, H., Hart, S.R., and Richardson, S.H., 1981. Alteration of the oceanic crust: processes and timing. Earth Planet. Sci. Lett., 52:311-327.

Thompson, G., 1983. Basalt-seawater interaction. In Rona, P.A., Boström, K., Laubier, L., and Smith, K.L., Jr. (Eds.), Hydrothermal Processes at Seafloor Spreading Centers: New York (Plenum), 225-278.

Wheat, C.G., and Mottl, M.G., 1994. Hydrothermal circulation, Juan de Fuca Ridge eastern flank: factors controlling basement water composition. $J$. Geophys. Res., 99:3067-3080.

\section{Date of initial receipt: 6 April 1995 \\ Date of acceptance: 1 August 1995 \\ Ms 148SR-150}

